Check for updates

Cite this: RSC Adv., 2019, 9, 7652

Received 6th January 2019

Accepted 4th February 2019

DOI: $10.1039 / c 9 r a 00118 b$

rsc.li/rsc-advances

\title{
A methanol and protic ionic liquid Ugi multicomponent reaction path to cytotoxic $\alpha$ - phenylacetamido amides $\dagger$
}

\author{
Ahmed Al Otaibi, $\$^{a}$ Fiona M. Deane, ${ }^{a}$ Cecilia C. Russell, ${ }^{a}$ Lacey Hizartzidis, ${ }^{a}$ \\ Siobhann N. McCluskey, ${ }^{a}$ Jennette A. Sakoff ${ }^{b}$ and Adam McCluskey (D) *a
}

\begin{abstract}
The Ugi four component reaction of an aldehyde, amine, isocyanide and an ethanoic acid was effected smoothly in protic ionic liquids ethylammonium nitrate (EAN) and propylammonium nitrate (PAN) to afford analogues of $\alpha$-phenylacetamido amides in good to excellent isolated yields. The corresponding reactions in $\left[\mathrm{BMIM}_{[}\left[\mathrm{PF}_{6}\right]\right.$ and the protic ionic liquid ethanolammonium nitrate (ETAN) failed. Microwave irradiation in EAN facilitated rapid access to three focused libraries, based on the parent isocyanide: cyclohexyl isocyanide, benzyl isocyanide and ethyl isocyanoacetate. Analysis of the structure activity relationship data suggested the presence of a bulky moiety originating from the isocyanide (cyclohexyl and benzyl) enhanced cytotoxicity. Removal of the acetylenic $\mathrm{H}$-atom from the ethanoic acid moiety was detrimental to cytotoxicity. The most active analogues produced, $\quad \mathrm{N}$-(2-cyclohexylamino)-1-(4-methoxyphenyl)-2-oxoethyl- $N$-(3,5-dimethoxyphenyl) propiolamide, returned average $\mathrm{Gl}_{50}$ values of $\leq 1 \mu \mathrm{M}$ across the cancer cell lines evaluated. Combined, these data suggest that analogues of this nature are interesting potential anti-cancer development leads.
\end{abstract}

\section{Introduction}

The ability to rapidly probe the subtle nuances of chemical space through the decoration of simple and complex chemical scaffolds is critical to the development of new therapeutics and new therapeutic lead compounds. ${ }^{1-7}$ Medicinal chemistry relies on a robust toolkit of chemical modification broadly applicable across a diverse array of chemotypes. These robust, reliable synthetic tools enable rapid development of structure activity relationship data, the installation of favourable physicochemical properties and the bioisosteric replacement of toxicophores that may stymy drug development endeavours. ${ }^{8-10}$

Multicomponent reactions (MCRs) are key 'medicinal toolkit' reactions permitting rapid assembly of three or more components in a one-pot sequence to produce a final product. ${ }^{11-20}$ MCRs present the medicinal chemist with additional benefits beyond rapid compound access and diversity, they are typically highly atom economic producing less waste

${ }^{a}$ Chemistry, School of Environmental \& Life Sciences, The University of Newcastle, University Drive, Callaghan, NSW 2308, Australia. E-mail: Adam.McCluskey@ newcastle.edu.au

${ }^{b}$ Department of Medical Oncology, Calvary Mater Newcastle Hospital, Edith Street Waratah 2298, Australia

$\dagger$ Electronic supplementary information (ESI) available. See DOI: 10.1039/c9ra00118b

\$ Present address: Department of Chemistry, Faculty of Science, University of Hail, Hail, Kingdom of Saudi Arabia. and require fewer resources, less time, energy and human effort. In many cases simpler purification processes and high convergence are also evident. ${ }^{\mathbf{1 3 2 1 - 2 4}}$ Isocyanide-based MCRs are one of the most important and widely used of all the MCRs, and have been extensively used in the development of biologically active compounds., , $13,24-28^{-1}$

The Ugi reaction is a well explored MCR for the generation of peptide like adducts, ${ }^{29-33}$ and as others and we have previously reported for the synthesis of heterocycles, e.g. quninolin-2-(1H)ones and tetrahydroepoxisindole carboxamides. ${ }^{34,35}$ In these programs we have an on-going interest in the development of cytotoxic compounds, as have others. Previously Yamada et al. demonstrated the 4-component Ugi reaction provided robust access to a small library of cytotoxic propynoic acid carbamoyl methyl amide (PCMA) derivatives such as 1 and 2 (Fig. 1). ${ }^{36}$
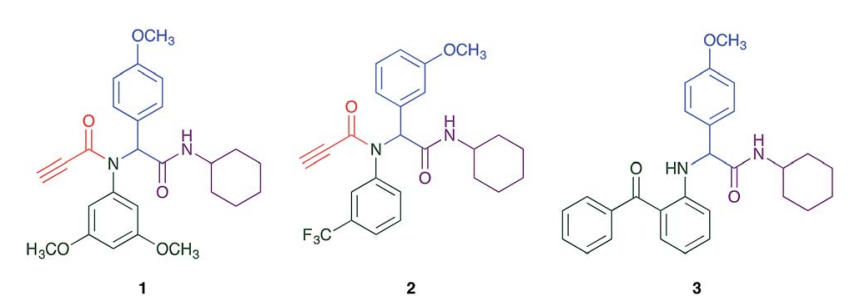

Fig. 1 Two examples for cytotoxic propynoic acid carbamoyl methyl amides (PCMA) synthesised by Yamada, ${ }^{36}$ and 3-component Ugi product from Gordon et al. ${ }^{34}$ 


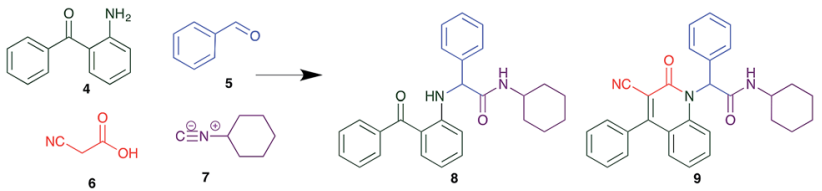

Scheme 1 Reagents and conditions: $\mathrm{CH}_{3} \mathrm{OH}$, rt.

Table 1 Effect of microwave irradiation time and reaction temperature on the isolated yield of the Ugi coupling of 5, 7, 10 and 11 in methanol to yield 12

\begin{tabular}{llcl}
\hline Entry & Time $(\mathrm{min})$ & Temp. ${ }^{\circ} \mathrm{C}$ & Yield\% \\
\hline 1 & 5 & 50 & 11 \\
2 & 5 & 100 & 58 \\
3 & 5 & 120 & 63 \\
4 & 10 & 120 & 69 \\
5 & 20 & 120 & 83 \\
6 & 30 & 120 & 78 \\
7 & $1 \mathrm{~h}$ & 120 & 70 \\
\hline
\end{tabular}

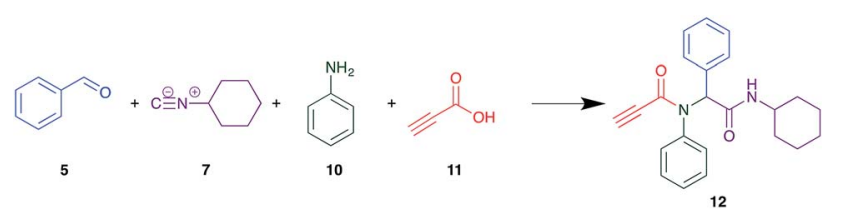

Scheme 2 Reagents and conditions: $\mathrm{CH}_{3} \mathrm{OH}, \mathrm{rt}-120^{\circ} \mathrm{C}$.
Table 3 The effect of PIL, microwave irradiation time and temperature on the yield of the Ugi coupling of 5, 7, 10 and 11 to yield 12

\begin{tabular}{|c|c|c|c|c|c|c|}
\hline \multirow[b]{3}{*}{ Entry } & \multirow[b]{3}{*}{ PIL } & \multicolumn{5}{|c|}{ Irradiation time } \\
\hline & & \multicolumn{3}{|l|}{$5 \mathrm{~min}$} & \multirow{2}{*}{$\frac{10 \mathrm{~min}}{120^{\circ} \mathrm{C}}$} & \multirow{2}{*}{$\frac{20 \mathrm{mir}}{120^{\circ} \mathrm{C}}$} \\
\hline & & $50^{\circ} \mathrm{C}$ & $100{ }^{\circ} \mathrm{C}$ & $120{ }^{\circ} \mathrm{C}$ & & \\
\hline 1 & EAN & $-^{a}$ & $58 \%$ & $60 \%$ & $62 \%$ & $61 \%$ \\
\hline 2 & PAN & $-^{a}$ & $51 \%$ & $55 \%$ & $60 \%$ & $54 \%$ \\
\hline 3 & ETAN & $-^{a}$ & $-a$ & $-a$ & $-{ }^{a}$ & $-^{a}$ \\
\hline
\end{tabular}

${ }^{a}$ No reaction, starting material recovered.

\section{Results and discussion}

The PCMA compounds $\mathbf{1}$ and $\mathbf{2}$ in Fig. 1 are related to a series of Ugi-products that we previously reported differing primarily the incorporation of an aminoketone, e.g. $3,^{34}$ but with these analogues we did not examine the cytotoxicity. In our hands a typical synthesis of this type of compound comprised the stirring of a methanolic solution of 2-aminobenzophenone (4) with benzaldehyde (5) followed by the addition of cyanoacetic acid (6) and cyclohexylisocyanide (7) afforded access to a separable mixture of the Ugi product, 8 and the Ugi-Knoevenagel product 9 , Scheme 1 . However, each reaction required $48 \mathrm{~h}$ to afford a modest $55 \%$ isolated yield. ${ }^{34}$

As one of our team's drivers is enhancing green approaches to biologically active compounds, we explored alternative approaches that have been shown in other instances to

Table 2 Evaluation of the cytotoxicity $\left(\mathrm{Gl}_{50}(\mu \mathrm{M})\right)$ of $\alpha$-amino amide analogue (13) and quninolin-2-(1H)-one analogues (14 and 15$)$ against a panel of ten cancer cell lines. $\mathrm{Gl}_{50}$ is the concentration of drug that reduces cell growth by $50 \%$ relative to an untreated control

\begin{tabular}{|c|c|c|c|c|c|c|c|c|c|c|}
\hline Compound & $\mathrm{HT} 29^{a}$ & SW $480^{a}$ & MCF $-7^{b}$ & $\mathrm{~A} 2780^{c}$ & $\mathrm{H} 460^{d}$ & $\mathrm{~A} 431^{e}$ & Du145 ${ }^{f}$ & $\mathrm{BE} 2-\mathrm{C}^{g}$ & $\mathrm{SJ}-\mathrm{G} 2^{h}$ & MIA $^{i}$ \\
\hline & $6.4 \pm 0.8$ & $6.0 \pm 0.4$ & $6.0 \pm 2.5$ & $7.0 \pm 1.5$ & $12 \pm 0$ & $11 \pm 0$ & $11 \pm 1$ & $5.4 \pm 0.9$ & $6.7 \pm 0.9$ & $6.9 \pm 1.2$ \\
\hline
\end{tabular}

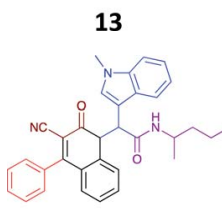

$5.3 \pm 0.3 \quad 11 \pm$

$4.6 \pm 1.1$

$3.9 \pm 0.3$

$5.2 \pm 0.1$

$2.7 \pm 0.3$

$13 \pm 0$

$3.6 \pm 0.1$

$6.5 \pm 0.3$

$6.0 \pm 0.1$

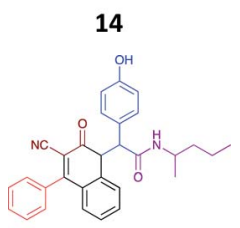

$8.7 \pm 0.5 \quad 17 \pm 1$

$7.9 \pm 1$

$7.5 \pm 0.6$

$11 \pm 1$

$6.3 \pm 0.5$

$18 \pm 1$

$7.3 \pm 0.3$

$10 \pm 1$

$13 \pm 1$

15

\footnotetext{
${ }^{a}$ HT29 and SW480 (colon carcinoma). ${ }^{b}$ MCF-7 (breast carcinoma). ${ }^{c}$ A2780 (ovarian carcinoma). ${ }^{d}$ H460 (lung carcinoma). ${ }^{e}$ A431 (skin carcinoma).

${ }^{f}$ Du145 (prostate carcinoma). ${ }^{g}$ BE2-C (neuroblastoma). ${ }^{h}$ SJ-G2 and U87 (glioblastoma). ${ }^{i}$ MIA (pancreatic carcinoma).
} 
enhance, and accelerate, reaction efficiency. ${ }^{37-44}$ Microwave irradiation of a model system, only expected to produce the linear Ugi product, comprising 5, 7, 10 and 11 in methanol was evaluated at $50{ }^{\circ} \mathrm{C}, 100{ }^{\circ} \mathrm{C}$ and $120{ }^{\circ} \mathrm{C}$ and the outcomes presented in Table 1 (Scheme 2). ${ }^{45}$ After 5 min irradiation at $50{ }^{\circ} \mathrm{C}$ a precipitate was observed, however TLC analysis indicated a mixture of product and starting materials. Increasing the reaction temperature to $100{ }^{\circ} \mathrm{C}$ and then $120{ }^{\circ} \mathrm{C}$ for 5 min saw a significant increase in product yield (58\% and $63 \%$ respectively), and in these instances the collected precipitate was pure by ${ }^{1} \mathrm{H}$ NMR analysis $\left(\mathrm{ESI}^{+}\right)$. Irradiation of the reaction mixture for $20 \mathrm{~min}$ at $120{ }^{\circ} \mathrm{C}$ gave the desired 12 in an $83 \%$ isolated yield, representing a considerable enhancement over the initial 55\% yield and $48 \mathrm{~h}$ reaction time. Prolonged heating resulted in a lower isolated yield, presumably a function of product degradation.

Expansion of the range of amines, acids, aldehydes and isonitriles afforded access to a broader range of Ugi products (Scheme 1; Table 2 and ESI $\dagger$ for detail). Subsequent MTT phenotypic screening against a panel of ten cancer cell lines

Table 4 Isolated yields of $\alpha$-amino amides from the Ugi reaction in EAN under microwave irradiation conditions ${ }^{a}$

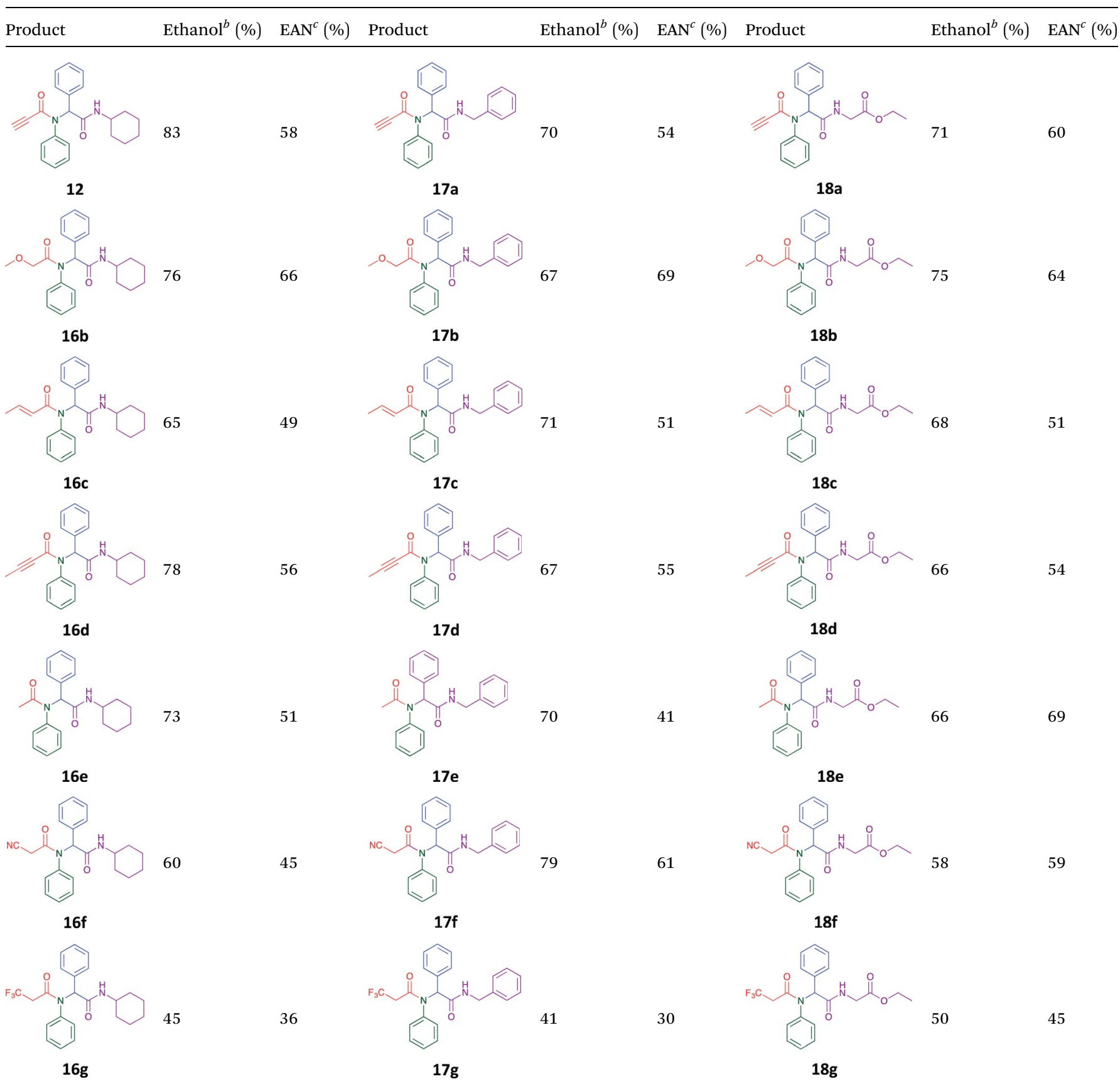

${ }^{a}$ Starting material recovered. ${ }^{b}$ At $120{ }^{\circ} \mathrm{C}$ for $20 \mathrm{~min}$ and using MeOH. ${ }^{c}$ At $120{ }^{\circ} \mathrm{C}$ by using microwave and EAN for $10 \mathrm{~min}$. 
Paper

View Article Online
RSC Advances

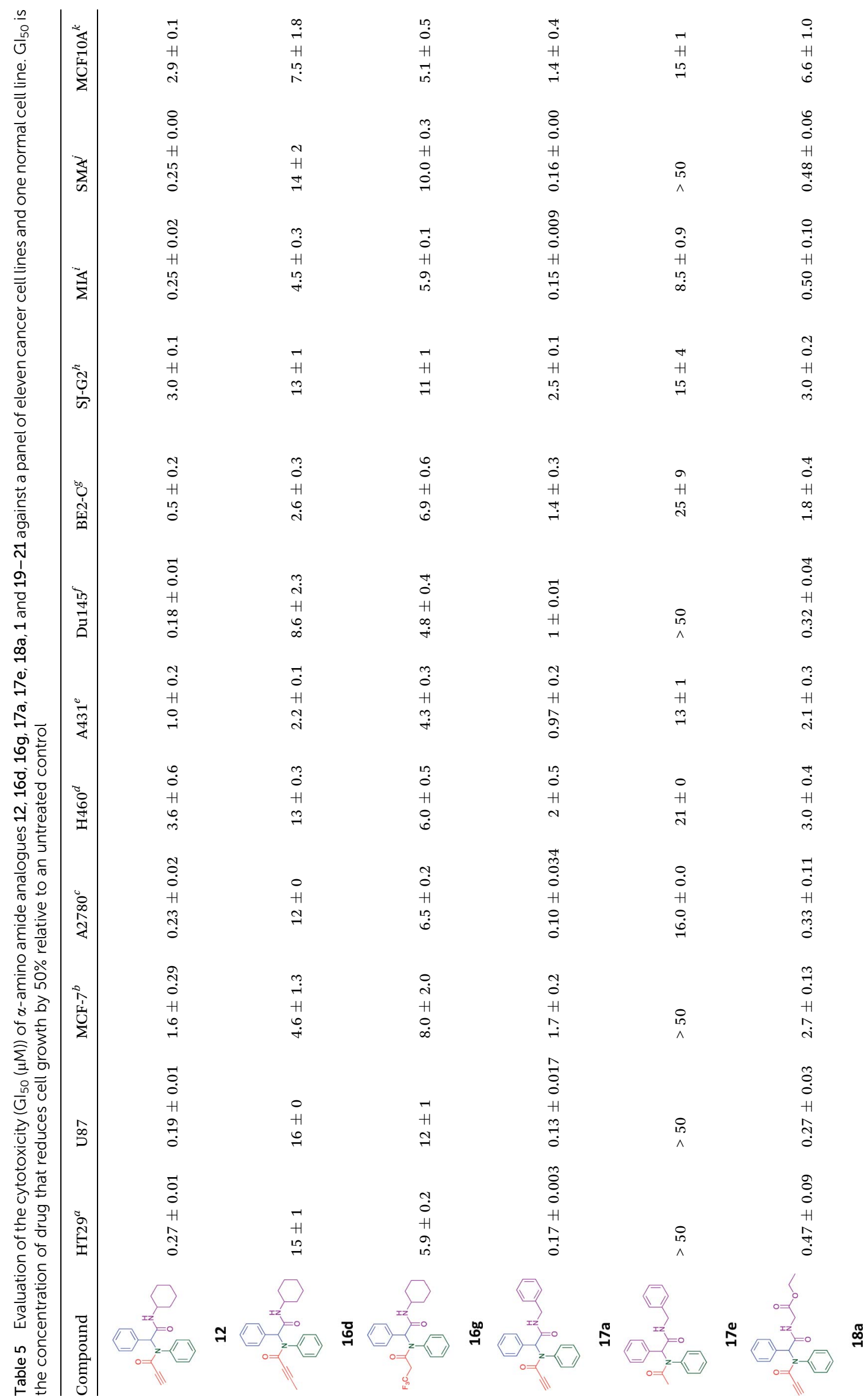

This journal is (c) The Royal Society of Chemistry 2019

RSC Adv., 2019, 9, 7652-7663 | 7655 


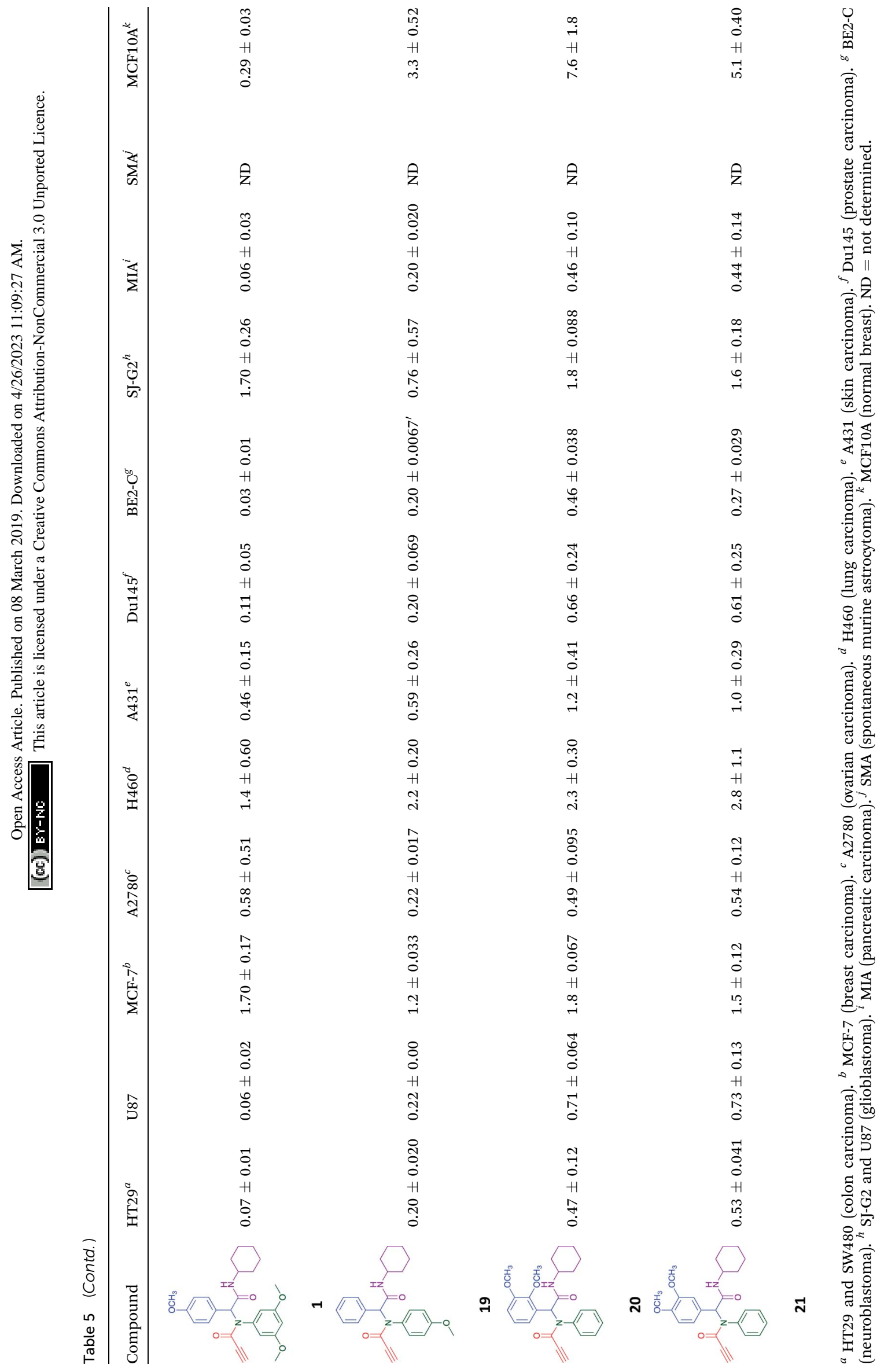


revealed modest levels of cytotoxicity at a single $25 \mu \mathrm{M}$ compound concentration. ${ }^{46}$ Only a small number of compounds, those with $>80 \%$ growth inhibition at $25 \mu \mathrm{M}$ against at least one cell line, from each of the $\alpha$-amino amides (7) and quinolone (8) compound series being sufficiently active to proceed to full dose response evaluation (Table 2).

While the observed cytotoxicity of 13, 14 and 15 was similar, with average $\mathrm{GI}_{50}$ values of $7.85,6.18$ and $10.7 \mu \mathrm{M}$ respectively, access to the Ugi-Knoevenagel intramolecularly cyclised product series was limited by the nature of the acid (requiring the presence of an acidic methylene moiety). Accordingly, we limited further compound development and cytotoxicity screening to new families of $\alpha$-amino amides.

Although microwave irradiation at $120{ }^{\circ} \mathrm{C}$ afforded excellent yields, this required the coupling to be conducted significantly above the boiling point of methanol with associated safety concerns. Accordingly, we sought a less volatile solvent, of which room temperature ionic liquids not only display the desired negligible to low vapour pressures, are environmentally friendly solvents, but as yet have not been explored for use in the Ugi coupling. ${ }^{47}$ Thus, Ugi coupling of 5, 7, 10 and 11 was explored in [BMIM] $\left[\mathrm{PF}_{6}\right]$. After $24 \mathrm{~h}$, despite allowing the imine from 3 and 5 to pre-form (Scheme 2), no product was observed at room temperature by TLC analysis. The same outcome was noted at $80{ }^{\circ} \mathrm{C}$ even after $24 \mathrm{~h}$, but at $100{ }^{\circ} \mathrm{C}$ and $120{ }^{\circ} \mathrm{C}, 20 \%$ and $32 \%$ product recovery was noted, however this was only after chromatographic separation.

In previous imine formation studies in our laboratory we noted an acceleration on imine formation on acid catalysis. ${ }^{35,48}$ We thus rationalised that this Ugi coupling might thus proceed more effectively in a protic ionic liquid. ${ }^{\mathbf{4 9 , 5 0}}$ This is in keeping with prior reports of efficient multicomponent reactions in ionic liquids and deep eutectic salts. ${ }^{51-55}$ The model coupling described above in each of, ethylammonium nitrate (EAN), propylammonium nitrate (PAN) and ethanol ammonium nitrate (ETAN) with microwave irradiation was evaluated after 5 min irradiation at $50{ }^{\circ} \mathrm{C}, 100{ }^{\circ} \mathrm{C}$ and $120{ }^{\circ} \mathrm{C}$ (Table 2). Pleasingly after $5 \mathrm{~min}$ irradiation at $100^{\circ} \mathrm{C}$, with EAN, a $58 \%$ recovery of pure 12 was achieved, increasing to $60 \%$ at $120{ }^{\circ} \mathrm{C}$ with a similar outcome noted with PAN. Interestingly ETAN was ineffectual, presumably a consequence of the pendent $\mathrm{OH}$ moiety (Table 3). As EAN returned the highest yields of 12 at both $100{ }^{\circ} \mathrm{C}$ and $120{ }^{\circ} \mathrm{C}$, this PIL was used in subsequent experiments.

Having demonstrated the efficacy of the Ugi coupling in this model system, we next examined the production of three isocyanide derived compound libraries through the use of cyclohexyl isocyanide, benzyl isocyanide, and ethyl isocyanoacetate, respectively, and a suite of diverse acids; propiolic, methoxyacetic, crotonic, 2-butynoic, acetic, cyanoacetic and 3,3,3-trifluoropropionic acids while retaining the parent aniline and benzaldehyde in the synthesis of three focused (12 and $\mathbf{1 6 b}-\mathbf{g}$; 17a-g; and 18a-g) libraries of $\alpha$-amino amides (see Scheme 2). In most instances the yields in EAN were comparable to that obtained on microwave irradiation in $\mathrm{MeOH}$ at $120{ }^{\circ} \mathrm{C}$ (Table 4).

The cytotoxicity of the each of the focused libraries (12 and 16b-g, 17a-g and 18a-g) compounds, were investigated in a modified panel of eleven tumour cell lines: colon (HT29, SW480), skin (A431), lung (H460), ovarian (A2780), breast (MCF7), prostate (Du145), pancreatic (MIA), glioblastoma (SJ-G2, SMA, U87), and neuroblastoma (BE2-C) and one non-cancer derived normal breast cell line (MCF10A). Compounds were initially screened at $25 \mu \mathrm{M}$ drug concentrations (ESI $\dagger$ ), and from this screening, analogues 12, 16d, 16g, 17a, 17e and 18a showed sufficiently promising activity to warrant full dose evaluation, and these data are presented in Table 5 .

Of the six analogues that proceeded to $\mathrm{GI}_{50}$ determination, exemplars from each isocyanide (cyclohexylisocyanide, benzylisocyanide and ethyl isocyanoacetate) library were present. Four analogues contained an acetylene moiety $(\mathbf{1 2}, \mathbf{1 6 d}, \mathbf{1 7} \mathbf{a}$ and 18a) with the other two derived from acetic (17e) and trifluoropropionic acid $(\mathbf{1 6 g})$. The cyclohexyl moiety was present in three of these analogues $(\mathbf{1 2}, \mathbf{1 6 d}$ and $\mathbf{1 6 g})$ and a benzyl moiety (17a and 17e) in two, suggesting a requirement for a bulky hydrophobic moiety on the right-hand side of the molecule (as drawn). Analogues retaining the acetylenic moiety $(\mathbf{1 2}, \mathbf{1 7 a}$ and 18a) were considerably more potent than the equivalent propargylic analogue (16d) with average $\mathrm{GI}_{50}$ values of $1.16 \mu \mathrm{M}, 0.97$ $\mu \mathrm{M}, 1.8 \mu \mathrm{M}$ and $9.4 \mu \mathrm{M}$ respectively. With the acetylenic series of compounds $(\mathbf{1 2}, \mathbf{1 7 a}$ and 18a) sub-micro molar levels of toxicity is noted against HT29, U87, A2780, MIA and SMA cell lines. Removal of the acetylene (or propargylic) moiety with 17a results in a $>30$ fold potency reduction (average $\mathrm{GI}_{50}$ value $>30$ $\mu \mathrm{M})$, but the introduction of a trifluoromethyl moiety with $\mathbf{1 6} \mathrm{g}$ results in an analogue equipotent with $\mathbf{1 6 d}$ with an average $\mathrm{GI}_{50}$ of $7.2 \mu \mathrm{M}$ (Table 5).

Given the clear enhanced cytotoxicity of analogues containing the acetylenic moiety, and the similarity to those from the Yamada report, ${ }^{30}$ we sought to directly compare both analogues sets and expand the pharmacophore of these compounds. Thus, we in-house synthesised lead 1 and three additional methoxy analogues (19-21) as per Scheme 2. Screening data for these four analogues $(\mathbf{1}, \mathbf{1 9 - 2 1})$ is presented in Table 5 . Analysis of these data is consistent with the acetylene moiety analogues being sub-micromolar cytotoxic with all four analogues returning average $\mathrm{GI}_{50}$ values $\leq 1 \mu \mathrm{M}$ for the cancer cell lines examined. Of note in this series of analogues was the removal of the aromatic methoxy moieties that saw a reduction in the observed toxicity towards the MCF10A normal breast cell line. This was most apparent on removal of those methoxy moieties originating from the starting aniline. Repositioning of the methoxy moieties to the starting benzaldehyde was tolerated in this series of analogues, with both the 2,3- and 3,4-dimethoxy disposed analogues showing a 10-fold selectivity for cancer the cancer cell lines versus the MCF10A normal cell line. This is a promising level of selectivity at this stage of compound exploration.

\section{Conclusions}

The Ugi coupling of an aldehyde, amine, isocyanide and ethanoic acid to afford analogues of $\alpha$-phenylacetamido amides in modest yield under microwave irradiation conditions in methanol. Solvent switching to the protic ionic liquids EAN and PAN 
afforded higher or comparable yields without the need to heat the reaction about the solvent boiling point as was the case with the methanol reaction, with reactions conducted at $120{ }^{\circ} \mathrm{C}$. Neither [BMIM] $\left[\mathrm{PF}_{6}\right]$ nor ETAN afforded useful yields of the desired products. Our prior studies have shown that the initial imine formation requires acid catalysis, with the free $\mathrm{OH}$ moiety of ETAN presumed to interfere with this reaction. The Ugi coupling in the presence of an acid with an acidic methylene moiety afforded an additional Ugi-Knoevenagel cyclised product, but given the need for the acid component to contain an additional $\alpha$-methylene requirement (which were of limited supply in our laboratory), our subsequent synthesis was directed at the four component Ugi products. From this, three focused libraries, based on the starting cyclohexylisocyanide, benzylisocyanide and ethyl isocyanoacetate, were produced in good to excellent yield.

The acetylene containing 12, 16d, 17a and 18a; acetic acid 17e and derived with the other two derived from acetic 17e and trifluoropropionic acid derived $\mathbf{1 6} \mathbf{g}$ displayed excellent broad spectrum cytotoxicity. Analysis of the structure activity relationship data suggested the presence of a bulky moiety originating from the isocyanide (cyclohexyl and benzyl) enhanced cytotoxicity. Removal of the acetylenic $\mathrm{H}$-atom was detrimental to cytotoxicity. The acetylene $\mathrm{H}$-atom retention was confirmed with the synthesis of Yamada's lead $\mathbf{1}$ and three additional analogues $\mathbf{1 9 - 2 1},{ }^{30}$ which were the most active analogues produced with an average $\mathrm{GI}_{50}$ of $\leq 1 \mu \mathrm{M}$ across the cancer cell lines evaluated. Removal and repositioning of the $N$-(3,5-dimethoxyphenyl) moieties of $\mathbf{1}$ retained cancer cell line activity while reducing cytotoxicity against the MCF10A normal cell line. While these analogues display no greater cytotoxicity relative to those reported by Yamada, ${ }^{36}$ they aid in the development of a PCMA cytotoxicity pharmacophore. Combined these data suggest that analogues 19-21, in particular, are interesting potential anti-cancer development leads.

\section{Experimental}

\section{Chemistry}

General Methods. All reagents were purchased from SigmaAldrich, AK Scientific, Matrix Scientific or Lancaster Synthesis and were used without purification. All solvents were re-distilled from glass prior to use.

${ }^{1} \mathrm{H}$ and ${ }^{13} \mathrm{C}$ NMR spectra were recorded on a Bruker Advance $^{\mathrm{TM}}$ AMX 400 at 400.13 and $100.62 \mathrm{MHz}$, respectively and Advance $^{\text {TM }}$ AMX 600 at 600.21 and $150.92 \mathrm{MHz}$, respectively. Chemical shifts $(\delta)$ are reported in parts per million (ppm) measured relative to the internal standards. Coupling constants $(J)$ are expressed in hertz $(\mathrm{Hz})$. Mass spectra were recorded on a Shimadzu LCMS 2010 EV and Agilent 6100 series single quadrupole LCMS using a mobile phase of 1:1 acetonitrile $: \mathrm{H}_{2} \mathrm{O}$ with $0.1 \%$ formic acid. The University of Wollongong, Australia, Mass Spectrometry User resource \& Research Facility (MSURRF) analysed samples for High Resolution Mass Spectrometry HRMS Analytical HPLC traces were obtained using a Shimadzu system possessing a SIL-20A autosampler, dual LC-20AP pumps, CBM-20A bus module, CTO-
20A column heater, and a SPD-20A UV/vis detector. This system was fitted with an Alltima ${ }^{\mathrm{TM}} \mathrm{C}_{18} 5 \mu \mathrm{m} 150 \mathrm{~mm} \times 4.6 \mathrm{~mm}$ column with solvent A: $0.06 \%$ trifluoroacetic acid (TFA) in water and solvent B: $0.06 \%$ TFA in $\mathrm{CH}_{3} \mathrm{CN}-\mathrm{H}_{2} \mathrm{O}(90: 10)$. In each case HPLC traces were acquired at a flow rate of $2.0 \mathrm{~mL} \mathrm{~min}{ }^{-1}$, gradient 10-100 (\%B), over $15.0 \mathrm{~min}$, with detection at $220 \mathrm{~nm}$ and $254 \mathrm{~nm}$.

Melting points were recorded on a Büchi Melting Point M565 instrument. IR spectra were recorded on a PerkinElmer Spectrum Two ${ }^{\text {TM }}$ FTIR Spectrometer with the UATR accessories. Thin layer chromatography (TLC) was performed on Merck 60 F254 pre-coated aluminium plates with a thickness of $0.2 \mathrm{~mm}$. Column chromatography was performed under 'flash' conditions on Merck silica gel 60 (230-400 mesh).

\section{In vitro growth inhibition assays}

All cell lines were cultured in a humidified atmosphere $5 \% \mathrm{CO}_{2}$ at $37{ }^{\circ} \mathrm{C}$. The cancer cell lines were maintained in Dulbecco's modified Eagle's medium (DMEM) (Trace Biosciences, Australia) supplemented with $10 \%$ foetal bovine serum, $10 \mathrm{mM}$ sodium bicarbonate penicillin (100 $\left.\mathrm{IU} \mathrm{mL}^{-1}\right)$, streptomycin (100 $\left.\mu \mathrm{g} \mathrm{mL}{ }^{-1}\right)$, and glutamine $(4 \mathrm{mM})$. The non-cancer MCF10A cell line was cultured in DMEM : F12 (1:1) cell culture media, 5\% heat inactivated horse serum, supplemented with penicillin (50 IU $\left.\mathrm{mL}^{-1}\right)$, streptomycin $\left(50 \mu \mathrm{g} \mathrm{mL}^{-1}\right), 20 \mathrm{mM}$ Hepes, L-glutamine (2 mM), epidermal growth factor $\left(20 \mathrm{ng} \mathrm{mL}^{-1}\right)$, hydrocortisone $\left(500 \mathrm{ng} \mathrm{mL} \mathrm{m}^{-1}\right)$, cholera toxin $\left(100 \mathrm{ng} \mathrm{mL}^{-1}\right.$ ), and insulin $\left(10 \mu \mathrm{g} \mathrm{mL}^{-1}\right)$. Cytotoxicity was determined by plating cells in duplicate in $100 \mathrm{~mL}$ medium at a density of 2500-4000 cells per well in 96 well plates. On day 0 , (24 h after plating) when the cells were in logarithmic growth, $100 \mu \mathrm{L}$ medium with or without the test agent was added to each well. After $72 \mathrm{~h}$ compound exposure growth inhibitory effects were evaluated using the MTT (3-[4,5-dimethyltiazol-2-yl]-2,5diphenyltetrazolium bromide) assay and absorbance read at $540 \mathrm{~nm}$. An eight point dose response curve was produced from which the $\mathrm{GI}_{50}$ value was calculated, representing the drug concentration at which cell growth was inhibited by $50 \%$ based on the difference between the optical density values on day 0 and those at the end of drug exposure. ${ }^{40}$

\section{Synthesis of $\alpha$-amino amides}

(RS)- $N$-(2-(Cyclohexylamino)-2-oxo-1-phenylethyl)- $N$-phenylpropiolamide (12)

Method A (batch reaction and using $\mathrm{MeOH}$ ). A solution of $\mathrm{MeOH}(5.0 \mathrm{~mL})$, aniline $(0.09 \mathrm{~mL}, 1.00 \mathrm{mmol})$, and benzaldehyde $(0.10 \mathrm{~mL}, 1.00 \mathrm{mmol})$ was stirred at room temperature for $0.5 \mathrm{~h}$. To the stirred solution was added propiolic acid $(0.06 \mathrm{~mL}$, $1.00 \mathrm{mmol}$ ) followed by the addition of cyclohexyl isocyanide $(0.11 \mathrm{~mL}, 1.00 \mathrm{mmol})$. The reaction mixture was stirred at room temperature for $24 \mathrm{~h}$ and the resulting precipitate was collected, washed with diethyl ether, and dried to afford (12) as a white solid without purification ( $0.20 \mathrm{~g}, 55 \%)$.

Method B (microwave reaction and using $\mathrm{MeOH}$ ). A solution of $\mathrm{MeOH}(3.0 \mathrm{~mL})$, aniline $(0.09 \mathrm{~mL}, 1.00 \mathrm{mmol})$, and benzaldehyde $(0.10 \mathrm{~mL} \mathrm{~g}, 1.00 \mathrm{mmol})$ was stirred at room temperature 
for $5 \mathrm{~min}$ at room temperature. Then, propiolic acid $(0.06 \mathrm{~mL}$, $1.00 \mathrm{mmol}$ ) followed by the addition of cyclohexyl isocyanide $(0.11 \mathrm{~mL}, 1.00 \mathrm{mmol})$ were added to the stirred solution. The microwave irradiation was applied for 20 min under $120{ }^{\circ} \mathrm{C}$. After 20 minutes the formation of a precipitate was observed, the solid was collected and washed with diethyl ether and dried to obtain the desired compound as a white solid $(0.30 \mathrm{~g}, 83 \%)$.

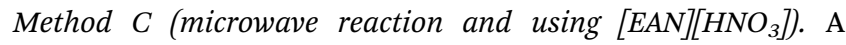
solution of $[\mathrm{EAN}]\left[\mathrm{HNO}_{3}\right](3.0 \mathrm{~mL})$, aniline $(0.09 \mathrm{~mL}, 1.00 \mathrm{mmol})$, and benzaldehyde $(0.10 \mathrm{~mL}, 1.00 \mathrm{mmol})$ was stirred at room temperature for $5 \mathrm{~min}$ at room temperature. Then propiolic acid and cyclohexylcyanide were added sequentially to the stirred solution and the reaction mixture was then irradiated at $120{ }^{\circ} \mathrm{C}$ for 20 minutes. Following irradiation the reaction mixture was extracted with EtOAC, washed with $\mathrm{H}_{2} \mathrm{O}$ and the combined organic layers dried over $\mathrm{MgSO}_{4}$ and concentrated in vacuo. Finally, the crude reaction mixture was subjected to flash silica gel column chromatography (Hexane : EtOAc) to afford pure product (12) $(0.21 \mathrm{~g}, 58 \%)$; LRMS $\left(\mathrm{ESI}^{+}\right) \mathrm{m} / \mathrm{z} 361[\mathrm{M}+\mathrm{H}]^{+}$; mp 194.1-196.7; IR $\left(\mathrm{cm}^{-1}\right)$ : 3278, 2924, 2848, 2113, 1640, 1594, 1563, 1491, 1452, 1359, 1308, 1250, 1106, 762, 730, 649, 660, 569. ${ }^{1} \mathrm{H}$ NMR (400 MHz, $\left.\mathrm{CDCl}_{3}\right): \delta 7.10-7.25(\mathrm{~m}, 10 \mathrm{H}), 6.01(\mathrm{~s}$, $1 \mathrm{H}), 5.58(\mathrm{~d}, J=8.2 \mathrm{~Hz}, 1 \mathrm{H}), 3.79-3.87(\mathrm{~m}, 1 \mathrm{H}), 2.79(\mathrm{~s}, 1 \mathrm{H})$, 1.80-1.98 (m, 1H), 1.79-1.88 (m, 1H), 1.52-1.71 (m, 3H), 1.25$1.40(\mathrm{~m}, 2 \mathrm{H}), 0.96-1.18(\mathrm{~m}, 3 \mathrm{H}) ;{ }^{13} \mathrm{C} \mathrm{NMR}$ (101 MHz, $\mathrm{CDCl}_{3}$ ): $\delta 167.7,153.9,139.2,133.9,130.9,130.5,128.9,128.6,80.7,76.2$, 65.2, 49.0, 32.9, 25.6, 24.9.

(RS)- $N$-Cyclohexyl-2-(2-methoxy- $N$-phenylacetamido)-2-phenylacetamide (16b). Synthesised using the general procedure (Method $\mathrm{b}$ and c) as described for (12) by using aniline (0.09 mL, 1.00 mmol), benzaldehyde $(0.10 \mathrm{~g}, 1.00 \mathrm{mmol})$, methoxyacetic acid $(0.07 \mathrm{~g}, 1.00 \mathrm{mmol})$, and cyclohexyl isocyanide $(0.11 \mathrm{~mL}, 1.00$ $\mathrm{mmol}$ ), to afford (16b) as a brown solid (Method b 76\% and 66\% c); LRMS (ESI $\left.{ }^{+}\right) \mathrm{m} / z 381[\mathrm{M}+\mathrm{H}]^{+}$; mp 210.1-214.3; IR (cm $\left.{ }^{-1}\right): 3260$, 3099, 2926, 2854, 1670, 1645, 1595, 1564, 1493, 1447, 1278, 1250, 1127, 976, 698, 557. ${ }^{1} \mathrm{H}$ NMR (400 $\left.\mathrm{MHz}, \mathrm{CDCl}_{3}\right): \delta 7.07-7.30(\mathrm{~m}$, $10 \mathrm{H}), 6.05(\mathrm{~s}, 1 \mathrm{H}), 5.58-5.63(\mathrm{~d}, J=8.0 \mathrm{~Hz}, 1 \mathrm{H}), 3.67-3.88(\mathrm{~m}, 3 \mathrm{H})$, $3.33(\mathrm{~s}, 3 \mathrm{H}), 1.90-2.00(\mathrm{~m}, 1 \mathrm{H}), 1.80-1.90(\mathrm{~d}, J=12.5 \mathrm{~Hz}, 1 \mathrm{H}), 1.24-$ 1.41 (q, $J=11.6 \mathrm{~Hz}, 2 \mathrm{H}), 0.96-1.19(\mathrm{~m}, 3 \mathrm{H}) ;{ }^{13} \mathrm{C} \mathrm{NMR}(101 \mathrm{MHz}$, $\left.\mathrm{CDCl}_{3}\right): \delta 169.9,168.5,138.5,134.4,130.6,130.6,129.1,128.6$, 128.5, 71.0, 65.1, 59.4, 49.0, 33.0, 32.9, 25.6, 25.0, 24.9.

$(R S)-(E)-N$-(2-(Cyclohexylamino)-2-oxo-1-phenylethyl)- $N$-phenylbut-2-enamide (16c). Synthesised using the general procedure (Method b and c) as described for (12) above from aniline $(0.09 \mathrm{~mL}$, $1.00 \mathrm{mmol})$, benzaldehyde $(0.10 \mathrm{~mL}, 1.00 \mathrm{mmol})$, crotonic acid $(0.23 \mathrm{~g}, 1.00 \mathrm{mmol})$, and cyclohexyl isocyanide $(0.11 \mathrm{~mL}, 1.00$ $\mathrm{mmol}$ ), to afford (16c) as a white solid (Method b 65\% and c 49\%); LRMS $\left(\mathrm{ESI}^{+}\right) \mathrm{m} / \mathrm{z} 377[\mathrm{M}+\mathrm{H}]^{+}, \mathrm{mp}$ 172.5-187.4; IR $\left(\mathrm{cm}^{-1}\right): 3266$, 2926, 2848, 1666, 1645, 1627, 1447, 1367, 1237, 1107, 960, 750, 697, 558. ${ }^{1} \mathrm{H}$ NMR (400 MHz, $\left.\mathrm{CDCl}_{3}\right): \delta 7.02-7.24(\mathrm{~m}, 10 \mathrm{H}), 6.90-7.02(\mathrm{~m}$, $1 \mathrm{H}), 6.03(\mathrm{~s}, 1 \mathrm{H}), 5.74-5.84(\mathrm{~d}, J=8.0 \mathrm{~Hz}, 1 \mathrm{H}), 5.57-5.65$ (dd, $J=$ 15.0, $1.7 \mathrm{~Hz}, 1 \mathrm{H}), 3.77-3.89$ (m, 1H), 1.90-1.99 (m, 1H), 1.81-1.90 $(\mathrm{m}, 1 \mathrm{H}), 1.52-1.73(\mathrm{~m}, 5 \mathrm{H}), 1.24-1.41(\mathrm{~m}, 3 \mathrm{H}), 0.97-1.20(\mathrm{~m}, 3 \mathrm{H}) ;{ }^{13} \mathrm{C}$ NMR (101 MHz, $\mathrm{CDCl}_{3}$ ): $\delta$ 168.7, 166.5, 142.3, 140.0, 134.9, 130.5, 130.2, 128.8, 128.3, 128.2, 127.9, 122.9, 65.6, 48.6, 32.9, 32.8, 25.5, 24.8, 24.7, 18.0 .
(RS)- $N$-(2-(Cyclohexylamino)-2-oxo-1-phenylethyl)- $N$-phenylbut2-enamide (16d). Synthesised using the general procedure (Method b and c) as described for (12) above from aniline $(0.09 \mathrm{~g}$, $1.00 \mathrm{mmol}$ ), benzaldehyde (0.10 mL, $1.00 \mathrm{mmol}), 2$-butynoic acid $(0.23 \mathrm{~g}, 1.00 \mathrm{mmol})$, and cyclohexyl isocyanide $(0.11 \mathrm{~mL}, 1.00$ $\mathrm{mmol})$ in $\mathrm{MeOH}(5.0 \mathrm{~mL})$ to afford (16d) as a white solid (Method b 78\% and c 56\%); LRMS (ESI $\left.{ }^{+}\right) m / z 375[\mathrm{M}+\mathrm{H}]^{+}$; mp 211.5-213.5; IR ( $\left.\mathrm{cm}^{-1}\right)$ : 3266, 2925, 2854, 2256, 1649, 1633, 1553, 1493, 1358, 1249, 1101, 979, 697, 661, 570. ${ }^{1} \mathrm{H}$ NMR (400 MHz, $\left.\mathrm{CDCl}_{3}\right): \delta 7.12-$ $7.23(\mathrm{~m}, 10 \mathrm{H}), 5.97-6.03(\mathrm{~s}, 1 \mathrm{H}), 5.63-5.72(\mathrm{~d}, J=8.2 \mathrm{~Hz}, 1 \mathrm{H}), 3.74-$ 3.88 (m, 1H), 1.90-1.98 (dd, $J=12.8,4.2 \mathrm{~Hz}, 1 \mathrm{H}), 1.80-1.89$ (m, $1 \mathrm{H}), 1.65-1.70(\mathrm{~d}, J=7.3 \mathrm{~Hz}, 7 \mathrm{H}), 1.26-1.41(\mathrm{~m}, 2 \mathrm{H}), 0.97-1.19(\mathrm{~m}$, $3 \mathrm{H}) ;{ }^{13} \mathrm{C} \mathrm{NMR}\left(101 \mathrm{MHz}, \mathrm{CDCl}_{3}\right): \delta 168.1,155.2,139.9,134.3,130.7$, 130.3, 128.6, 128.5, 128.4, 128.2, 91.5, 74.1, 65.1, 48.9, 32.9, 32.9, 25.6, 24.9, 24.8, 4.0.

(RS)- $N$-Cyclohexyl-2-phenyl-2-( $N$-phenylacetamido)acetamide (16e). Synthesised using the general procedure (Method b and c) as described for (12) from aniline $(0.09 \mathrm{~mL}, 1.00 \mathrm{mmol})$, benzaldehyde $(0.10 \mathrm{~g}, 1.00 \mathrm{mmol})$, acetic acid $(0.23 \mathrm{~g}, 1.00 \mathrm{mmol})$, and cyclohexyl isocyanide $(0.11 \mathrm{~mL}, 1.00 \mathrm{mmol})$ to afford (16e) as a white solid (Method b 73\%, and c 51\%); LRMS (ESI ${ }^{+}$) $\mathrm{m} / \mathrm{z} 351$ [M $+\mathrm{H}]^{+}$; mp 186.1-189.4; 3260, 2926, 2848, 1645, 1563, 1493, 1382, 1250, 1240, 889, 730, 696, 647, 548, 515. ${ }^{1} \mathrm{H}$ NMR (400 MHz, $\left.\mathrm{CDCl}_{3}\right): \delta 7.06-7.25(\mathrm{~m}, 10 \mathrm{H}), 5.99-6.03(\mathrm{~s}, 1 \mathrm{H}), 5.56-5.64(\mathrm{~d}, J=$ $7.8 \mathrm{~Hz}, 1 \mathrm{H}), 3.70-3.93$ (m, 1H), 1.89-1.9945 (m, 1H), 1.84-1.88 (s, $3 \mathrm{H}), 1.75(\mathrm{~s}, 1 \mathrm{H}), 1.52-1.71(\mathrm{~m}, 3 \mathrm{H}), 1.25-1.41$ (m, 2H), 0.96-1.18 $(\mathrm{m}, 3 \mathrm{H}) ;{ }^{13} \mathrm{C}$ NMR $\left(101 \mathrm{MHz}, \mathrm{CDCl}_{3}\right): \delta 171.3,168.9,140.9,134.9$, 130.4, 129.0, 128.4, 128.1, 65.2, 48.9, 33.0, 32.9, 25.6, 25.0, 24.9, 23.4.

(RS)-2-Cyano- $N$-(2-(cyclohexylamino)-2-oxo-1-phenylethyl)- $N$ phenylacetamide (16f). Synthesised using the general procedure (Method b and c) as described for (12) from aniline $(0.09 \mathrm{~mL}$, $1.00 \mathrm{mmol})$, benzaldehyde ( $0.10 \mathrm{~g}, 1.00 \mathrm{mmol})$, cyanoacetic acid $(0.23 \mathrm{~g}, 1.00 \mathrm{mmol})$, and cyclohexyl isocyanide $(0.11 \mathrm{~mL}, 1.00$ $\mathrm{mmol}$ ), to afford (16f) as a white solid (Method b 60\% and $\mathrm{c}$ 45\%); LRMS (ESI $\left.{ }^{+}\right) m / z 376[\mathrm{M}+\mathrm{H}]^{+} ; \mathrm{mp} 241.9-245.4 ; \mathrm{IR}\left(\mathrm{cm}^{-1}\right)$ : 3253, 2928, 2858, 1668, 1643, 1594, 1563, 1493, 1386, 1239, 1104, 1005, 734, 697, 408. ${ }^{1} \mathrm{H}$ NMR (400 $\left.\mathrm{MHz} \mathrm{CDCl}_{3}\right): \delta 7.05-$ $7.31(\mathrm{~m}, 10 \mathrm{H}), 5.99-6.02(\mathrm{~s}, 1 \mathrm{H}), 5.38-5.44(\mathrm{~d}, J=8.1 \mathrm{~Hz}, 1 \mathrm{H})$, 3.75-3.87 (m, 1H), 3.1281-3.2897 (m, 2H), 1.89-1.99 (dd, $J=$ 12.0, $4.1 \mathrm{~Hz}, 1 \mathrm{H}), 1.77-1.88$ (m, 1H), 1.6245-1.71 (m, 2H), 1.231.42 (m, 3H), 0.93-1.17 (m, 3H); ${ }^{13} \mathrm{C} \mathrm{NMR} \mathrm{(101} \mathrm{MHz,} \mathrm{CDCl}_{3}$ ): $\delta 167.9,162.7,138.6,133.8,130.5,129.3,129.1,128.8,65.8,49.2$, 33.0, 32.9, 26.4, 25.6, 25.0, 24.9.

(RS)-N-(2-(Cyclohexylamino)-2-oxo-1-phenylethyl)-3,3,3-trifluoro- $\boldsymbol{N}$-phenylpropanamide (16g). Synthesised using the general procedure (Method b and c) as described for (12) from aniline $(0.09 \mathrm{~mL}, 1.00 \mathrm{mmol})$, benzaldehyde $(0.10 \mathrm{~g}, 1.00$ $\mathrm{mmol}), 3,3,3$-trifluoropropionic acid $(0.23 \mathrm{~g}, 1.00 \mathrm{mmol})$, and cyclohexyl isocyanide $(0.11 \mathrm{~mL}, 1.00 \mathrm{mmol})$ to afford $(\mathbf{1 6 g})$ as a white solid (Method b 45\% and c 36\%); LRMS (ESI ${ }^{+}$) $\mathrm{m} / \mathrm{z} 377$ $[\mathrm{M}+\mathrm{H}]^{+}$; mp 202.9-211.9; IR $\left(\mathrm{cm}^{-1}\right): 3327(\mathrm{NH}), 3056(\mathrm{CH})$, 2961, $2929(\mathrm{CH}) ;{ }^{1} \mathrm{H}$ NMR (400 MHz, $\left.\mathrm{CDCl}_{3}\right): \delta$ 6.95-7.46 (m, $10 \mathrm{H}), 6.03(\mathrm{~s}, 1 \mathrm{H}), 5.46-5.56(\mathrm{~d}, J=8.1 \mathrm{~Hz}, 1 \mathrm{H}), 3.74-3.86(\mathrm{~m}$, $1 \mathrm{H}), 2.83-3.02(\mathrm{~m}, 2 \mathrm{H}), 1.89-1.98$ (dd, $J=13.3,4.3 \mathrm{~Hz}, 2 \mathrm{H}$ ), 1.79-1.88 (m, 1H), 1.52-1.72 (m, 3H), 1.40-1.47 (d, $J=9.1 \mathrm{~Hz}$, 
1H), 1.24-1.40 (m, 2H), 0.93-1.17 (m, 3H). ${ }^{13} \mathrm{C}$ NMR (101 MHz, $\left.\mathrm{CDCl}_{3}\right) \delta 168.2,164.1,164.1,139.0,134.1,130.5,128.9,128.8$, 128.6, 65.3, 49.0, 39.5, 39.2, 38.9, 38.6, 32.9, 32.9, 25.6, 24.1, 24.9.

$(R S)-N$-(2-(Benzylamino)-2-oxo-1-phenylethyl)- $N$-phenylpropiolamide (17a). Synthesised using the general procedure (Method b and c) as described for (12) from aniline $(0.09 \mathrm{~mL}$, $1.00 \mathrm{mmol})$, benzaldehyde $(0.10 \mathrm{~g}, 1.00 \mathrm{mmol})$, propiolic acid $(0.06 \mathrm{~g}, 1.00 \mathrm{mmol})$, and benzyl isocyanide $(0.12 \mathrm{~mL}, 1.00$ $\mathrm{mmol}$ ), to afford (17a) as a white solid (Method b 70\% and c 54\%); LRMS $\left(\mathrm{ESI}^{+}\right) \mathrm{m} / z 369[\mathrm{M}+\mathrm{H}]^{+}, \mathrm{mp}$ 184.1-194.9; IR $\left(\mathrm{cm}^{-1}\right)$ : 3307 (NH), 3189, 1668, 1635 (C); ${ }^{1} \mathrm{H}$ NMR (400 MHz, $\mathrm{CDCl}_{3}$ ):

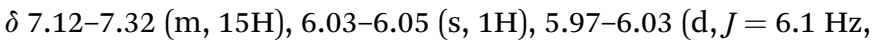
$1 \mathrm{H}), 4.44-4.56(\mathrm{~m}, 2 \mathrm{H}), 3.45-3.49(\mathrm{~s}, 1 \mathrm{H}) ;{ }^{13} \mathrm{C}$ NMR $(101 \mathrm{MHz}$, $\left.\mathrm{CDCl}_{3}\right): \delta 168.7,153.9,139.2,137.9,133.5,130.9,130.5,128.8$, 128.7, 128.7, 127.7, 127.6, 80.8, 65.4, 51.0, 44.0.

(RS)- $N$-Benzyl-2-(2-methoxy- $N$-phenylacetamido)-2-phenylacetamide (17b). Synthesised using the general procedure (Method b and c) as described for (12) from aniline $(0.09 \mathrm{~mL}$, $1.00 \mathrm{mmol})$, benzaldehyde $(0.10 \mathrm{~g}, 1.00 \mathrm{mmol})$, methoxyacetic acid (0.07 mL, $1.00 \mathrm{mmol})$, and benzyl isocyanide $(0.12 \mathrm{~mL}, 1.00$ $\mathrm{mmol}$ ) to afford (17b) as a white solid (Method b 67\% and c 69\%); LRMS $\left(\mathrm{ESI}^{+}\right) \mathrm{m} / z 389[\mathrm{M}+\mathrm{H}]^{+}$. Mp 182.5-185.7; IR $\left(\mathrm{cm}^{-1}\right)$ : 3255 (NH), 1664, 1651 (CO); ${ }^{1} \mathrm{H}$ NMR (400 MHz, $\left.\mathrm{CDCl}_{3}\right): \delta 7.07-$ $7.33(\mathrm{~m}, 15 \mathrm{H}), 6.62-6.68(\mathrm{~m}, 1 \mathrm{H}), 6.09(\mathrm{~s}, 1 \mathrm{H}), 4.46-4.52(\mathrm{dd}, J=$ 8.6, $5.8 \mathrm{~Hz}, 1 \mathrm{H}), 3.68-3.81$ (d, $J=1.6 \mathrm{~Hz}, 2 \mathrm{H}), 3.42$ (s, 1H), 3.34 $(\mathrm{s}, 2 \mathrm{H}) ;{ }^{13} \mathrm{C}$ NMR $\left(101 \mathrm{MHz}, \mathrm{CDCl}_{3}\right): \delta 170.0,169.5,138.4,138.1$, $133.9,130.6,130.5,129.6,129.2$, 129.1, 128.8, 128.8, 128.7, $128.7,128.6,128.1,127.7,127.5,119.7,113.9,71.0,65.3,59.4$, 44.0 .

$(R S)-(E)-N$-(2-(Benzylamino)-2-oxo-1-phenylethyl)- $N$-phenylbut2-enamide (17c). Synthesised using the general procedure (Method $\mathrm{b}$ and c) as described for (12) from aniline (0.09 $\mathrm{mL}, 1.00 \mathrm{mmol})$, benzaldehyde $(0.10 \mathrm{~g}, 1.00 \mathrm{mmol})$, crotonic acid $(0.23 \mathrm{~g}, 1.00$ $\mathrm{mmol})$, and benzyl isocyanide $(0.12 \mathrm{~mL}, 1.00 \mathrm{mmol})$, to afford $(\mathbf{1 7 c})$ as a white solid (Method b 71\% and c 51\%); LRMS (ESI ${ }^{+}$) $m / z 385$ $[\mathrm{M}+\mathrm{H}]^{+}$; mp 208.9-221.7; IR $\left(\mathrm{cm}^{-1}\right): 3337$ (NH), 1657, 1620 (CO); ${ }^{1} \mathrm{H}$ NMR (400 MHz, $\left.\mathrm{CDCl}_{3}\right): \delta 7.03-7.31(\mathrm{~m}, 15 \mathrm{H}), 6.92-7.03(\mathrm{~m}$, $1 \mathrm{H}), 6.25(\mathrm{~s}, 1 \mathrm{H}), 6.08(\mathrm{~s}, 1 \mathrm{H}), 5.59-5.66(\mathrm{dd}, J=15.1,1.7 \mathrm{~Hz}, 1 \mathrm{H})$, $4.48-4.54(\mathrm{~d}, J=5.8 \mathrm{~Hz}, 2 \mathrm{H}), 1.68-1.74(\mathrm{dd}, J=7.0,1.7 \mathrm{~Hz}, 3 \mathrm{H}) ;{ }^{13} \mathrm{C}$ NMR (101 MHz, $\mathrm{CDCl}_{3}$ ): $\delta$ 169.9, 166.7, 142.6, 140.1, 138.3, 134.7, 130.6, 130.4, 129.0, 128.7, 128.5, 128.5, 128.1, 127.7, 127.4, 123.0, 66.0, 43.9, 18.2 .

(RS)- $N$-(2-(Benzylamino)-2-oxo-1-phenylethyl)- $N$-phenylbut2-ynamide (17d). Synthesised using the general procedure (Method b and c) as described for (12) above from aniline (0.09 $\mathrm{mL}, 1.00 \mathrm{mmol})$, benzaldehyde (0.10 g, $1.00 \mathrm{mmol}), 2$-butynoic acid $(0.23 \mathrm{~g}, 1.00 \mathrm{mmol})$, and benzyl isocyanide $(0.12 \mathrm{~mL}, 1.00$ $\mathrm{mmol}$ ), to afford (17d) as a white solid (Method b 67\% and c 55\%); LRMS $\left(\mathrm{ESI}^{+}\right) \mathrm{m} / z 383[\mathrm{M}+\mathrm{H}]^{+} ; \mathrm{mp}$ 183.1-187.8; IR $\left(\mathrm{cm}^{-1}\right)$ : $3298(\mathrm{NH}), 2249,1164,1629$ (CO); ${ }^{1} \mathrm{H}$ NMR (400 MHz, $\mathrm{CDCl}_{3}$ ): $\delta 7.26-7.30(\mathrm{~m}, 2 \mathrm{H}), 7.16-7.25(\mathrm{~m}, 13 \mathrm{H}), 6.07-6.12(\mathrm{~d}, J=6.1 \mathrm{~Hz}$, 1H), $6.03(\mathrm{~s}, 1 \mathrm{H}), 4.34-4.63(\mathrm{~m}, 3 \mathrm{H}), 1.67$ (s, 3H); ${ }^{13} \mathrm{C}$ NMR (101 $\left.\mathrm{MHz}, \mathrm{CDCl}_{3}\right): \delta 169.1,155.2,139.9,138.0,134.0,130.7,130.4$, 128.8, 128.8, 128.6, 128.5, 128.3, 127.7, 127.5, 91.6, 74.1, 65.4, $44.0,4.0$.
(RS)-N-Benzyl-2-phenyl-2-( $N$-phenylacetamido)acetamide (17e). Synthesised using the general procedure (Method b and c) as described for (12) from aniline $(0.09 \mathrm{~mL}, 1.00 \mathrm{mmol})$, benzaldehyde (0.10 g, $1.00 \mathrm{mmol})$, acetic acid (0.23 g, $1.00 \mathrm{mmol})$, and benzyl isocyanide $(0.12 \mathrm{~mL}, 1.00 \mathrm{mmol})$, to afford (17e) as a white solid (Method b 70\% and c 41\%); LRMS (ESI ${ }^{+}$) m/z $359[\mathrm{M}+\mathrm{H}]^{+}$; mp 185.2-188.7; IR ( $\left.\mathrm{cm}^{-1}\right)$ : 3247 (NH), 1652, 1645 (CO); ${ }^{1} \mathrm{H}$ NMR $\left(400 \mathrm{MHz} \mathrm{CDCl}_{3}\right): \delta 1.65-1.69(\mathrm{~s}, 1 \mathrm{H}), 1.85-1.88(\mathrm{~s}, 3 \mathrm{H}), 4.43-4.55$ $(\mathrm{m}, 2 \mathrm{H}), 6.03-6.12(\mathrm{~d}, J=10.4 \mathrm{~Hz}, 2 \mathrm{H}), 7.06-7.32(\mathrm{~m}, 15 \mathrm{H}) ;{ }^{13} \mathrm{C}$ $\mathrm{NMR}\left(101 \mathrm{MHz}, \mathrm{CDCl}_{3}\right): \delta 171.4,169.9,140.9,138.2,134.6,130.5$, 130.4 , 129.1, 128.8, 128.6, 128.5, 128.2, 127.7, 127.5, 65.4, 43.9, 23.4.

(RS)- $N$-Benzyl-2-(2-cyano- $N$-phenylacetamido)-2-phenylacetamide (17f). Synthesised utilising the general procedure described in (12) from aniline $(0.09 \mathrm{~mL}, 1.00 \mathrm{mmol})$, benzaldehyde (0.10 g, $1.00 \mathrm{mmol})$, cyanoacetic acid $(0.23 \mathrm{~g}, 1.00$ $\mathrm{mmol})$, and benzyl isocyanide $(0.12 \mathrm{~mL}, 1.00 \mathrm{mmol})$, to afford (17f) as a brown solid (Method b 79\% and c 61\%); LRMS (ESI ${ }^{+}$) $\mathrm{m} / \mathrm{z} 389[\mathrm{M}+\mathrm{H}]^{+} ; \mathrm{mp}$ 216.1-221.1; IR $\left(\mathrm{cm}^{-1}\right): 3256(\mathrm{NH}), 1664$, 1654 (CO); ${ }^{1} \mathrm{H}$ NMR (400 MHz, $\left.\mathrm{CDCl}_{3}\right): \delta 3.15-3.29(\mathrm{~m}, 2 \mathrm{H})$, 4.41-4.55 (m, 2H), 5.91 (s, 1H), $6.05(\mathrm{~s}, 1 \mathrm{H}), 7.08-7.29(\mathrm{~m}, 15 \mathrm{H})$; ${ }^{13} \mathrm{C}$ NMR (101 MHz, $\mathrm{CDCl}_{3}$ ): $\delta 168.9,162.8,138.6,137.8,130.6$, 129.3, 129.2, 128.8, 128.8, 127.7, 127.7, 114.1, 65.9, 44.1, 26.5.

(RS)- $\mathrm{N}$-(2-(Benzylamino)-2-oxo-1-phenylethyl)-3,3,3-trifluoro$\boldsymbol{N}$-phenylpropanamide (17g). Synthesised using the general procedure (Method b and c) as described for (12) from aniline (0.09 mL, $1.00 \mathrm{mmol}$ ), benzaldehyde ( $0.10 \mathrm{~g}, 1.00 \mathrm{mmol}), 3,3,3-$ trifluoropropionic acid $(0.23 \mathrm{~g}, 1.00 \mathrm{mmol})$, and benzyl isocyanide $(0.12 \mathrm{~mL}, 1.00 \mathrm{mmol})$, to afford $(\mathbf{1 7 g})$ as a white solid (Method b 41\% and c 30\%); LRMS (ESI ${ }^{+}$m/z $427[\mathrm{M}+\mathrm{H}]^{+}$, mp 160.8-164.4; IR (cm ${ }^{-1}$ ): 3266 (NH), 1666, 1654 (CO); ${ }^{1} \mathrm{H}$ NMR $\left(400 \mathrm{MHz}, \mathrm{CDCl}_{3}\right): \delta 7.54-7.79(\mathrm{~s}, 1 \mathrm{H}), 7.14-7.31(\mathrm{~m}, 11 \mathrm{H}), 7.09-$ $7.13(\mathrm{~m}, 2 \mathrm{H}), 6.42-6.68(\mathrm{~s}, 1 \mathrm{H}), 6.06-6.10(\mathrm{~s}, 1 \mathrm{H}), 5.93-6.00(\mathrm{~s}$, $1 \mathrm{H}), 4.38-4.58(\mathrm{~m}, 2 \mathrm{H}), 2.82-3.06(\mathrm{~m}, 2 \mathrm{H}) ;{ }^{13} \mathrm{C}$ NMR $(101 \mathrm{MHz}$, $\left.\mathrm{CDCl}_{3}\right): \delta 169.0,133.6,130.4,128.9,128.7,128.6,127.6,127.5$, 95.0, 65.3, 43.9.

(RS)-Ethyl (2-phenyl-2-( $N$-phenylpropiolamido)acetyl)glycinate (18a). Synthesised using the general procedure (Method b and c) as described for (12) above from aniline (0.09 $\mathrm{mL}, 1.00 \mathrm{mmol})$, benzaldehyde $(0.10 \mathrm{~g}, 1.00 \mathrm{mmol})$, propiolic acid $(0.06 \mathrm{~g}, 1.00$ $\mathrm{mmol})$, and ethyl isocyanoacetate $(0.11 \mathrm{~mL}, 1.00 \mathrm{mmol})$, to afford (18a) as a white solid (Method b 71\% and c 60\%); LRMS (ESI $\left.{ }^{+}\right) \mathrm{m} / \mathrm{z}$ $365[\mathrm{M}+\mathrm{H}]^{+} ; \operatorname{mp} 170.5-172.2 ; \mathrm{IR}\left(\mathrm{cm}^{-1}\right): 3333(\mathrm{NH}), 1625(\mathrm{CO}) ;{ }^{1} \mathrm{H}$ NMR (400 MHz, $\left.\mathrm{CDCl}_{3}\right): \delta 7.12-7.25(\mathrm{~m}, 10 \mathrm{H}), 6.31-6.36(\mathrm{~s}, 1 \mathrm{H})$, 6.11-6.15 (s, 1H), 4.13-4.20 (q, $J=7.1 \mathrm{~Hz}, 2 \mathrm{H}), 4.02-4.06(\mathrm{t}, J=$ $5.1 \mathrm{~Hz}, 2 \mathrm{H}), 2.77-2.82(\mathrm{~s}, 1 \mathrm{H}), 2.01-2.03(\mathrm{~s}, 1 \mathrm{H}), 1.22-1.26(\mathrm{t}, J=$ $7.1 \mathrm{~Hz}, 4 \mathrm{H}) .{ }^{13} \mathrm{C}$ NMR (101 MHz, $\left.\mathrm{CDCl}_{3}\right): \delta 169.6,168.9,153.9$, 139.0, 133.2, 130.8, 130.6, 129.0, 128.7, 128.7, 128.6, 80.8, 76.1, 64.9, 61.6, 60.5, 41.8, 21.1, 14.2.

(RS)-Ethyl (2-(2-methoxy- $N$-phenylacetamido)-2-phenylacetyl) glycinate (18b). Synthesised using the general procedure (Method B and C) as described for (12) from aniline $(0.09 \mathrm{~mL}$, $1.00 \mathrm{mmol})$, benzaldehyde $(0.10 \mathrm{~mL}, 1.00 \mathrm{mmol})$, methoxyacetic acid $(0.08 \mathrm{~mL}, 1.00 \mathrm{mmol})$, and ethyl isocyanoacetate $(0.12 \mathrm{~mL}$, $1.00 \mathrm{mmol}$ ), to afford (18b) as a white solid (Method B 0.29, 75\% and Method C $0.25 \mathrm{~g}, 65 \%)$; LRMS $\left(\mathrm{ESI}^{+}\right) \mathrm{m} / z 385[\mathrm{M}+\mathrm{H}]^{+}$; mp 
170-178 ${ }^{\circ} \mathrm{C}$; IR $\left(\mathrm{cm}^{-1}\right): 3330(\mathrm{NH}), 1627(\mathrm{CO}) ;{ }^{1} \mathrm{H}$ NMR $(400 \mathrm{MHz}$, $\left.\mathrm{CDCl}_{3}\right) \delta$ 7.26-7.13 (m, 10H), 6.43-6.40 (m, 1H), $6.18(\mathrm{~s}, 1 \mathrm{H}), 4.12$ $(\mathrm{q}, J=7.2 \mathrm{~Hz}, 2 \mathrm{H}), 4.00(\mathrm{t}, J=5.5 \mathrm{~Hz}, 2 \mathrm{H}), 3.69(\mathrm{~s}, 2 \mathrm{H}), 3.27(\mathrm{~s}$, $3 \mathrm{H}), 1.20(\mathrm{t}, J=7.1 \mathrm{~Hz}, 3 \mathrm{H}) ;{ }^{13} \mathrm{C} \mathrm{NMR}\left(101 \mathrm{MHz}, \mathrm{CDCl}_{3}\right) \delta 169.9$, 169.7, 169.6, 138.1, 133.6, 130.6, 130.4, 129.0, 128.6, 128.6, 128.3, 70.8, 64.6, 61.3, 59.2, 41.6, 14.1 .

$(R S)-(E)$-Ethyl 2-(2-phenyl-2-( $N$-phenylbut-2-enamido)acetamido) acetate (18c). Synthesised using the general procedure (Method $\mathrm{b}$ and c) as described for (12) from aniline (0.09 g, $1.00 \mathrm{mmol})$, benzaldehyde $(0.10 \mathrm{~g}, 1.00 \mathrm{mmol})$, crotonic acid $(0.23 \mathrm{~g}, 1.00 \mathrm{mmol})$, and ethyl isocyanoacetate $(0.11 \mathrm{~mL}, 1.00 \mathrm{mmol})$, to afford $(\mathbf{1 8 c})$ as a white solid (Method b 68\% and c 51\%); LRMS (ESI ${ }^{+}$) $\mathrm{m} / \mathrm{z} 381[\mathrm{M}+$ $\mathrm{H}]^{+}$, mp 181.9-187.2; IR ( $\left.\mathrm{cm}^{-1}\right)$ : $3331(\mathrm{NH}), 1662,1625(\mathrm{CO}) ;{ }^{1} \mathrm{H}$ NMR $\left(400 \mathrm{MHz}, \mathrm{CDCl}_{3}\right) \delta$ 7.15-7.25 (m, 9H), 6.91-7.02 (dd, $J=15.0$, $6.9 \mathrm{~Hz}, 2 \mathrm{H}), 6.54-6.59$ (s, 1H), 6.10-6.14 (s, 1H), 5.58-5.66 (dd, $J=$ 15.1, $1.7 \mathrm{~Hz}, 1 \mathrm{H}), 4.14-4.21$ (q, $J=7.2 \mathrm{~Hz}, 2 \mathrm{H}), 4.05-4.09(\mathrm{dd}, J=5.3$, $3.2 \mathrm{~Hz}, 2 \mathrm{H}), 1.67-1.72$ (dd, $J=7.0,1.7 \mathrm{~Hz}, 3 \mathrm{H}), 1.22-1.27(\mathrm{t}, J=$ $7.1 \mathrm{~Hz}, 4 \mathrm{H}) ;{ }^{13} \mathrm{C} \mathrm{NMR}\left(101 \mathrm{MHz}, \mathrm{CDCl}_{3}\right) \delta 170.0,169.8,166.7,142.8$, $140.0,134.3$, 134.2, 130.5, 130.4, 129.0, 128.5, 128.4, 128.1, 122.8, 115.4, 65.7, 61.5, 41.7, 18.2, 14.2.

(RS)-Ethyl (2-phenyl-2-( $N$-phenylbut-2-ynamido)acetyl)glycinate (18d). Synthesised using the general procedure (Method b and c) as described for (12) from aniline $(0.09 \mathrm{~mL}, 1.00 \mathrm{mmol})$, benzaldehyde (0.10 g, $1.00 \mathrm{mmol}), 2$-butynoic acid (0.23 g, $1.00 \mathrm{mmol})$, and ethyl isocyanoacetate $(0.11 \mathrm{~mL}, 1.00 \mathrm{mmol})$, to afford (18b) as a white solid (Method b 66\% and c 54\%); LRMS (ESI ${ }^{+}$) $\mathrm{m} / \mathrm{z} 379[\mathrm{M}+$ $\mathrm{H}^{+}$; mp 175.6-178.4; IR ( $\left.\mathrm{cm}^{-1}\right)$ : 3337 (NH), 1657, 1620 (CO), 1594, $1549 ;{ }^{1} \mathrm{H}$ NMR $\left(400 \mathrm{MHz}, \mathrm{CDCl}_{3}\right): \delta 7.11-7.24(\mathrm{~m}, 11 \mathrm{H}), 6.35(\mathrm{~s}, 1 \mathrm{H})$, $6.11(\mathrm{~s}, 1 \mathrm{H}), 4.14-4.22(\mathrm{q}, J=7.1 \mathrm{~Hz}, 2 \mathrm{H}), 4.03-4.10(\mathrm{~d}, J=5.3 \mathrm{~Hz}$, $2 \mathrm{H}), 1.63-1.70(\mathrm{~s}, 3 \mathrm{H}), 1.22-1.29(\mathrm{t}, J=7.1 \mathrm{~Hz}, 3 \mathrm{H}) ;{ }^{13} \mathrm{C}$ NMR $(101$ $\left.\mathrm{MHz}, \mathrm{CDCl}_{3}\right): \delta 169.6,169.3,155.2,139.7,133.6,130.6,130.5$, 128.8, 128.5, 128.5, 128.3, 91.7, 74.0, 64.9, 61.6, 60.5, 41.8, 21.1, 14.3, 14.2, 4.0 .

(RS)-Ethyl (2-(2-methoxy- $N$-phenylacetamido)-2-phenylacetyl) glycinate (18e). Synthesised using the general procedure (Method b and c) as described for (12) from aniline $(0.09 \mathrm{~g}, 1.00$ $\mathrm{mmol})$, benzaldehyde $(0.10 \mathrm{~g}, 1.00 \mathrm{mmol})$, acetic acid $(0.23 \mathrm{~g}, 2.70$ $\mathrm{mmol})$, and ethyl isocyanoacetate $(0.11 \mathrm{~mL}, 1.00 \mathrm{mmol})$, to afford (18e) as a white solid (Method b 66\% and c 69\%); LRMS (ESI ${ }^{+}$) $\mathrm{m} / \mathrm{z}$ $355[\mathrm{M}+\mathrm{H}]^{+}, \operatorname{mp} 183.6-186.1$. IR $\left(\mathrm{cm}^{-1}\right): 3244,3085,3061,1655$; ${ }^{1} \mathrm{H}$ NMR (400 MHz, $\mathrm{CDCl}_{3}$ ): $\delta 6.97-7.18(\mathrm{~m}, 10 \mathrm{H}), 6.59-6.65(\mathrm{t}, J=$ $5.4 \mathrm{~Hz}, 1 \mathrm{H}), 6.11-6.15(\mathrm{~s}, 1 \mathrm{H}), 4.06-4.14(\mathrm{q}, J=7.1 \mathrm{~Hz}, 2 \mathrm{H}), 3.95-$ $4.01(\mathrm{dd}, J=6.6,5.4 \mathrm{~Hz}, 2 \mathrm{H}), 1.76-1.79(\mathrm{~s}, 3 \mathrm{H}), 1.15-1.21(\mathrm{t}, J=$ $7.1 \mathrm{~Hz}, 3 \mathrm{H}) ;{ }^{13} \mathrm{C}$ NMR $\left(101 \mathrm{MHz}, \mathrm{CDCl}_{3}\right): \delta 171.2,170.0,169.6$, $140.5,134.2$, 130.5, 130.2, 128.8, 128.3, 128.2, 128.0, 64.6, 61.3, $41.5,23.1,14.1$.

(RS)-Ethyl 2-(2-(2-cyano- $\mathrm{N}$-phenylacetamido)-2-phenylacetamido) acetate (18f). Synthesised using the general procedure (Method $\mathrm{b}$ and c) as described for (12) from aniline (0.09 $\mathrm{mL}, 1.00 \mathrm{mmol})$, benzaldehyde $(0.10 \mathrm{~g}, 1.00 \mathrm{mmol})$, cyanoacetic acid $(0.23 \mathrm{~g}, 2.70$ $\mathrm{mmol})$, and ethyl isocyanoacetate $(0.11 \mathrm{~mL}, 1.00 \mathrm{mmol})$, to afford (18f) as a white solid (Method b 58\% and c 59\%); LRMS (ESI ${ }^{+}$) $\mathrm{m} / \mathrm{z}$ $380[\mathrm{M}+\mathrm{H}]^{+} ; \mathrm{mp}$ 168.2-172.2. IR $\left(\mathrm{cm}^{-1}\right): 3397(\mathrm{NH}), 2205$ (CN) 1660, 1624 (CO); ${ }^{1} \mathrm{H}$ NMR (400 MHz, $\mathrm{CDCl}_{3}$ ): $\delta$ 7.05-7.33 (m, 10H), 6.15$6.21(\mathrm{~s}, 1 \mathrm{H}), 6.14(\mathrm{~s}, 1 \mathrm{H}), 4.14-4.21$ (q, J= 7.2 Hz, 2H), 4.01-4.10 (dd, $J=6.9,5.3 \mathrm{~Hz}, 2 \mathrm{H}), 3.15-3.29(\mathrm{~m}, 2 \mathrm{H}), 1.22-1.28$ (t, $J=7.1 \mathrm{~Hz}, 3 \mathrm{H})$.
${ }^{13} \mathrm{C} \mathrm{NMR}\left(101 \mathrm{MHz}, \mathrm{CDCl}_{3}\right): \delta 169.6,169.1,162.9,138.5,133.0,130.8$, 130.4, 129.4, 129.2, 128.8, 114.0, 65.6, 61.7, 41.8, 26.4, 14.2.

(RS)-Ethyl (2-phenyl-2-(3,3,3-trifluoro- $N$-phenylpropanamido) acetyl)glycinate (18g). Synthesised using the general procedure (Method b and c) as described for (12) from aniline $(0.09 \mathrm{~mL}, 1.00$ mmol), benzaldehyde $(0.10 \mathrm{~g}, 1.00 \mathrm{mmol}), 3,3,3$-trifluoropropionic acid $(0.23 \mathrm{~g}, 1.00 \mathrm{mmol})$, and ethyl isocyanoacetate $(0.11 \mathrm{~mL}, 1.00 \mathrm{mmol})$, to afford $(\mathbf{1 8 g})$ as a white solid (Method b 50\% and c 45\%); LRMS (ESI ${ }^{+}$) $m / z 423[\mathrm{M}+\mathrm{H}]^{+}$, mp 164.2-166.5. IR ( $\left.\mathrm{cm}^{-1}\right): 3393(\mathrm{NH}), 2206(\mathrm{CN})$ 1660, 1624 (CO); ${ }^{1} \mathrm{H}$ NMR (400 MHz, $\left.\mathrm{CDCl}_{3}\right): \delta 7.56-7.74(\mathrm{~s}, 1 \mathrm{H}), 7.02-7.42$ $(\mathrm{m}, 9 \mathrm{H}), 6.46-6.64(\mathrm{~d}, J=7.1 \mathrm{~Hz}, 1 \mathrm{H}), 6.19-6.25(\mathrm{~s}, 1 \mathrm{H}), 6.12-6.16$ $(\mathrm{s}, 1 \mathrm{H}), 4.13-4.21(\mathrm{q}, J=7.1 \mathrm{~Hz}, 2 \mathrm{H}), 4.03-4.08(\mathrm{dd}, J=5.3,2.7 \mathrm{~Hz}$, $2 \mathrm{H}), 2.83-3.03(\mathrm{qd}, J=10.0,7.9 \mathrm{~Hz}, 2 \mathrm{H}), 1.21-1.27(\mathrm{t}, J=7.1 \mathrm{~Hz}$, 3H). ${ }^{13} \mathrm{C} \mathrm{NMR} \mathrm{(101} \mathrm{MHz,} \mathrm{CDCl}_{3}$ ): $\delta$ 169.6, 169.3, 164.2, 164.2, 138.9, 133.4, 130.7, 130.5, 129.0, 128.7, 65.2, 61.7, 41.8, 39.5, 39.2, 38.9, 38.6, 14.2 .

(RS)-N-(2-(Cyclohexylamino)-2-oxo-1-phenylethyl)- $N$-(4-methoxyphenyl)propiolamide (19). Synthesised using the general procedure (method a) from 4-methoxybenzaldehyde $(0.136 \mathrm{~g}, 1.00$ $\mathrm{mmol})$, 2-butynoic acid (0.23 g, $1.00 \mathrm{mmol})$, aniline (0.9 mL, 1.00 $\mathrm{mmol}$ ) and cyclohexyl isocyanide $(0.11 \mathrm{~mL}, 1.00 \mathrm{mmol})$ to afford (19) as a white solid (0.259 g, 66\%) LRMS $m / z 391[\mathrm{M}+\mathrm{H}]^{+} \mathrm{mp}$ : 169-172; ${ }^{1} \mathrm{H}$ NMR (400 MHz, $\mathrm{CDCl}_{3}$ ) $\delta 7.24-7.20$ (m, 3H, signal overlaps residual $\left.\mathrm{CHCl}_{3}\right), 7.17-7.16(\mathrm{~m}, 2 \mathrm{H}), 7.09(\mathrm{t}, J=8.1 \mathrm{~Hz}, 1 \mathrm{H})$, $6.79(\mathrm{dd}, J=8.2,2.2 \mathrm{~Hz}, 2 \mathrm{H}), 6.74$ (bs s, 1H), 5.96 (s, 1H), 5.53 (d, $=7.7 \mathrm{~Hz}, 1 \mathrm{H}), 3.87-3.78(\mathrm{~m}, 1 \mathrm{H}), 3.66, \mathrm{~s}, 3 \mathrm{H}), 2.82(\mathrm{~s}, 1 \mathrm{H}) 1.89$ (dd, $J=34.5,10.4 \mathrm{~Hz}, 2 \mathrm{H}), 1.68-1.56$ (m, 3H, signal overlaps residual water), $1.40-1.28$ (m, 2H), 1.17-0.98 (m, 3H); ${ }^{13} \mathrm{C}$ NMR (101 MHz, $\left.\mathrm{CDCl}_{3}\right) \delta 167.7,159.7,153.8,140.3,134.0,130.4$ (2C), 129.2, 128.9, 128.7 (2C), 123.2, 115.8, 115.1, 80.5, 76.2, 65.4, 55.5, 49.0, 32.95, 32.90, 25.6, 24.9, 24.8.

(RS)-N-(2-(Cyclohexylamino)-1-(2,3-dimethoxyphenyl)-2-oxoethyl)- $\boldsymbol{N}$-phenylpropiolamide (20). Synthesised by method A from 2,3-dimethoxybenzaldehyde ( $0.166 \mathrm{~g}, 1.00 \mathrm{mmol}), 2$-butynoic acid $(0.23 \mathrm{~g}, 1.00 \mathrm{mmol})$, aniline $(0.9 \mathrm{~mL}, 1.00 \mathrm{mmol})$ and cyclohexyl isocyanide $(0.11 \mathrm{~mL}, 1.00 \mathrm{mmol})$ to afford (20) as a white solid $(0.2682 \mathrm{~g}, 64 \%)$. LRMS $m / z 421.2[\mathrm{M}+\mathrm{H}]^{+} \mathrm{mp} 224$ (dec); ${ }^{1} \mathrm{H}$ NMR (400 MHz, $\mathrm{CDCl}_{3}$ ) $\delta$ 7.24-7.17 (m, 5H), 6.82-6.74 $(\mathrm{m}, 2 \mathrm{H}), 6.59(\mathrm{dd}, J=7.4,1.4 \mathrm{~Hz}, 1 \mathrm{H}), 6.40(\mathrm{~s}, 1 \mathrm{H}), 5.49(\mathrm{~d}, J=$ $7.5 \mathrm{~Hz}, 1 \mathrm{H}), 3.84-3.77(\mathrm{~m}, 7 \mathrm{H}), 2.78$ (s, 1H), 1.89 (dd, $J=38.5$, $10.8 \mathrm{~Hz}, 2 \mathrm{H}), 1.70-1.55$ (m, 3H, signal overlaps residual water), 1.40-1.27 (m, 2H), 1.16-0.97 (m, 3H); ${ }^{13} \mathrm{C}$ NMR (101 MHz, $\left.\mathrm{CDCl}_{3}\right) \delta 168.1,153.8,152.5,147.9,139.5,130.7$ (2C), 128.59, 128.56 (2C), 127.8, 123.7, 122.8, 113.2, 80.4, 76.4, 61.1, 58.8, 55.9, 49.0, 33.0, 32.90, 25.6, 25.0, 24.9.

(RS)-N-(2-(Cyclohexylamino)-1-(3,4-dimethoxyphenyl)-2-oxoethyl)- $\boldsymbol{N}$-phenylpropiolamide (21). Synthesised by method A from 2,3-dimethoxybenzaldehyde ( $0.166 \mathrm{~g}, 1.00 \mathrm{mmol}), 2$-butynoic acid $(0.23 \mathrm{~g}, 1.00 \mathrm{mmol})$, aniline $(0.9 \mathrm{~mL}, 1.00 \mathrm{mmol})$ and cyclohexyl isocyanide $(0.11 \mathrm{~mL}, 1.00 \mathrm{mmol})$ to afford (21) as a white solid $(0.231 \mathrm{~g}, 55 \%)$. LRMS $m / z 421.2[\mathrm{M}+\mathrm{H}]^{+1} \mathrm{H}$ NMR $\left(400 \mathrm{MHz}, \mathrm{CDCl}_{3}\right) \delta 7.24-7.17(\mathrm{~m}, 5 \mathrm{H}$, overlapping signal with $\left.\mathrm{CDCl}_{3}\right), 6.77-6.69(\mathrm{~m}, 2 \mathrm{H}), 6.51(\mathrm{~s}, 1 \mathrm{H}), 6.00(\mathrm{~s}, 1 \mathrm{H}), 5.57(\mathrm{~d}, J=$ $7.6 \mathrm{~Hz}, 1 \mathrm{H}), 3.83(\mathrm{~s}, 3 \mathrm{H}) 3.81-3.75(\mathrm{~m}, 1 \mathrm{H}), 3.60(\mathrm{~s}, 3 \mathrm{H}), 2.80(\mathrm{~s}$, $1 \mathrm{H}), 1.88$ (dd, $J=48.3,11.2 \mathrm{~Hz}, 2 \mathrm{H}), 1.69-1.56$ (m, 3H, overlapping signal with residual water), 1.39-1.28 (m, 2H), 1.16-0.98 
$(\mathrm{m}, 3 \mathrm{H}) ;{ }^{13} \mathrm{C}$ NMR $\left(101 \mathrm{MHz}, \mathrm{CDCl}_{3}\right) \delta 168.0,153.9,149.44$, 148.7, 139.0, 131.10 (2C), 128.69, 128.66 (2C), 126.1, 123.4 (2C), 113.4, 110.7, 80.7, 64.3, 55.9, 55.8, 49.0, 32.9 (2C), 25.6, 24.9, 24.8 .

\section{Conflicts of interest}

The authors declare no conflict of interest.

\section{Acknowledgements}

AAO thanks the Saudi Arabian government for the provision of a PhD scholarship. AM acknowledges project funding from the Australian Research Council.

\section{Notes and references}

1 J. Hartwig, J. B. Metternich, N. Nikbin, A. Kirschning and S. V. Ley, Org. Biomol. Chem., 2014, 12, 3611-3615.

2 S. D. Roughley and A. M. Jordan, J. Med. Chem., 2011, 54, 3451-3479.

3 W. P. Walters, J. Green, J. R. Weiss and M. A. Murcko, J. Med. Chem., 2011, 54, 6405-6416.

4 M. C. Bellucci, M. Sani, A. Sganappa and A. Volonterio, ACS Comb. Sci., 2014, 16, 711-720.

5 H. Eckert, Molecules, 2012, 17, 1074-1102.

6 E. Vitaku, D. T. Smith and J. T. Njardarson, J. Med. Chem., 2014, 57, 10257-10274.

7 S. L. Schreiber, Science, 2000, 287, 1964-1969.

8 P. H. Olesen, Curr. Opin. Drug Discovery Dev., 2001, 4, 471478.

9 T. S. Elliott, A. Slowey, Y. Ye and S. J. Conway, Med. Chem. Commun., 2012, 3, 735-751.

10 N. A. Meanwell, J. Med. Chem., 2011, 54, 2529-2591.

11 R. C. Cioc, E. Ruijter and R. Orru, Green Chem., 2014, 29582975.

12 S. Brauch, S. S. van Berkel and B. Westermann, Chem. Soc. Rev., 2013, 42, 4948-4962.

13 T. Zarganes-Tzitzikas, A. L. Chandgude and A. Dömling, Chem. Rec., 2015, 15, 981-996.

14 S. Sharma, R. A. Maurya, K.-I. Min, G.-Y. Jeong and D.-P. Kim, Angew. Chem., Int. Ed. Engl., 2013, 52, 7564-7568.

15 C. Hulme, M. Ayaz, G. Martinez-Ariza, F. Medda and A. Shaw, Recent Advances in Multicomponent Reaction Chemistry: Applications in Small Molecule Drug Discovery in Small molecule medicinal chemistry: strategies and technologies, Wiley-Blackwell, 2015, pp. 145-187, DOI: 10.1002/ 9781118771723.ch6.

16 M. M. Khan, R. Yousuf and S. Khan, $R S C A d v ., 2015$, 5, 57883-57905.

17 S. Shaabani and A. Doemling, Angew. Chem., Int. Ed., 2018, 57, 16266-16268.

18 M. Mamaghani, R. H. Nia, F. Tavakoli and P. Jahanshahi, Curr. Org. Chem., 2018, 22, 1704-1769.

19 L. S. Longo and M. V. Craveiro, J. Braz. Chem. Soc., 2018, 29, 1999-2025.
20 I. A. Ibarra, A. Islas-Jacome and E. Gonzalez-Zamora, Org. Biomol. Chem., 2018, 16, 1402-1418.

21 D. J. Vugts, M. M. Koningstein, R. F. Schmitz, F. J. J. de Kanter, M. B. Groen and R. V. A. Orru, Chem.-Eur. J., 2006, 12, 7178-7189.

22 N. Isambert, M. D. M. S. Duque, J.-C. Plaquevent, Y. Génisson, J. Rodriguez and T. Constantieux, Chem. Soc. Rev., 2011, 40, 1347.

23 Z. El Asri, Y. Génisson, F. Guillen, O. Baslé, N. Isambert, M. del Mar Sanchez Duque, S. Ladeira, J. Rodriguez, T. Constantieux and J.-C. Plaquevent, Green Chem., 2011, 13, 2549.

24 J.-N. Tan, M. Li and Y. Gu, Green Chem., 2010, 12, 908.

25 J. E. Biggs-Houck, A. Younai and J. T. Shaw, Curr. Opin. Chem. Biol., 2010, 14, 371-382.

26 C.-V. T. Vo and J. W. Bode, J. Org. Chem., 2014, 79, 28092815.

27 A. Dömling and Y. Huang, Synthesis, 2010, 2010, 2859-2883. 28 R. W. Waller, L. J. Diorazio, B. A. Taylor, W. B. Motherwell and T. D. Sheppard, Tetrahedron, 2010, 66, 6496-6507.

29 C. E. M. Salvador, B. Pieber, P. M. Neu, A. Torvisco, C. Kleber, Z. Andrade and C. O. Kappe, J. Org. Chem., 2015, 80, 45904602.

30 V. Rai, S. Singh, P. Singh and L. Yadav, Synthesis, 2010, 40514056.

31 Y. Méndez, K. Pérez-Labrada, J. González-Bacerio, G. Valdés, M. Á. de los Chávez, J. Osuna, J.-L. Charli, I. Pascual and D. G. Rivera, ChemMedChem, 2014, 9, 2351-2359.

32 A. de F. S. Barreto, O. E. Vercillo, M. A. Birkett, J. C. Caulfield, L. A. Wessjohann and C. K. Z. Andrade, Org. Biomol. Chem., 2011, 9, 5024-5027.

33 A. Dömling, W. Wang and K. Wang, Chem. Rev., 2012, 112, 3083-3135.

34 C. P. Gordon, K. A. Young, L. Hizartzidis, F. M. Deane and A. McCluskey, Org. Biomol. Chem., 2011, 9, 1419-1428.

35 C. P. Gordon, K. A. Young, M. J. Robertson, T. A. Hill and A. McCluskey, Tetrahedron, 2011, 67, 554-561.

36 R. Yamada, X. Cao, A. N. Butkevich, M. Millard, S. Odde, N. Mordwinkin, R. Gundla, E. Zandi, S. G. Louie, N. A. Petasis and N. Neamati, J. Med. Chem., 2011, 54, 2902-2914.

37 F. M. Deane, A. Lin, P. G. Hains, S. L. Pilgrim, P. J. Robinson and A. McCluskey, J. Phys. Chem., 2017, 2, 3828-3838.

38 A. McCluskey, P. J. Robinson, T. Hill, J. L. Scott and J. K. Edwards, Tetrahedron Lett., 2002, 43, 3117-3120.

39 Z. M. A. Judeh, C. B. Ching, J. Bu and A. McCluskey, Tetrahedron Lett., 2002, 43, 5089-5091.

40 K. A. MacGregor and A. McCluskey, Tetrahedron Lett., 2011, 52, 767-769.

41 K. Booker, M. C. Bowyer, C. I. Holdsworth and A. McCluskey, Chem. Commun., 2006, 1730-1732.

42 C. P. Gordon, N. Byrne and A. McCluskey, Green Chem., 2010, 12, 1000 .

43 M. Tarleton and A. McCluskey, Tetrahedron Lett., 2011, 52, 1583-1586. 
44 T. N. Trinh, L. Hizartzidis, A. J. S. Lin, D. G. Harman, A. McCluskey and C. P. Gordon, Org. Biomol. Chem., 2014, 12, 9562-9571.

45 C. O. Kappe, Angew. Chem., Int. Ed., 2004, 43, 6250-6284.

46 J. R. Baker, J. Gilbert, S. Paula, X. Zhu, J. A. Sakoff and A. McCluskey, ChemMedChem, 2018, 13, 1447-1458.

47 J. P. Hallett and T. Welton, Chem. Rev., 2011, 111, 3508-3576. 48 C. P. Gordon, B. Venn-Brown, M. J. Robertson, K. A. Young, N. Chau, A. Mariana, A. Whiting, M. Chircop, P. J. Robinson and A. McCluskey, J. Med. Chem., 2013, 56, 46-59.

49 H. J. Jiang, S. Imberti, B. A. Simmons, R. Atkin and G. Warr, ChemSusChem, 2019, 12, 270-274.
50 T. L. Greaves and C. J. Drummond, Chem. Rev., 2015, 115, 11379-11448.

51 Z. Soeyler, K. N. Onwukamike, S. Grelier, E. Grau, H. Cramail and M. A. R. Meier, Green Chem., 2018, 2, 214-224.

52 S. T. Handy, in Ionic Liquids: Current State of the Art, InTech Publishing, 2015, pp. 59-92, DOI: 10.5772/59254.

53 S. Baghery, M. A. Zolfigol and F. Maleki, New J. Chem., 2017, 41, 9276-9290.

54 S. Sobhani, F. Zarifi and J. Skibsted, New J. Chem., 2017, 41, 6219-6225.

55 M. Yarie, M. A. Zolfigol, Y. Bayat, A. Asgari, D. A. Alonso and A. Khoshnood, RSC Adv., 2016, 6, 82842-82853. 